\title{
Anti-Inflammatory Plant Natural Products for Cancer Therapy
}

Authors

Affiliation
Kandan Aravindaram, Ning-Sun Yang

Agricultural Biotechnology Research Center, Academia Sinica, Nankang, Taipei, Taiwan, R. O. C.

Key words
angiogenesis
antioxidant
danger signals
detoxification
inflammation
metastasis
pathogens
stress
transcription factors
wound healing

received January 14, 2010

revised March 25, 2010

accepted March 29, 2010

Bibliography

DoI http://dx.doi.org/

10.1055/s-0030-1249859

Published online April 29, 2010

Planta Med 2010; 76:

1103-1117 C Georg Thieme

Verlag KG Stuttgart · New York ·

ISSN 0032-0943

\section{Correspondence}

Dr. Ning-Sun Yang

Agricultural Biotechnology

Research Center

Agricultural Technology

Building

Academia Sinica

No. 128, Sec. 2, Academia Road

Nankang

Taipei 11529

Taiwan

Republic of China

Phone: +886227872067

Fax: + 886226511127

nsyang@gate.sinica.edu.tw

\section{Abstract}

$\nabla$

Much of the current research in cancer therapeutics is aimed at developing drugs or vaccines to target key molecules for combating tumor cell growth, metastasis, proliferation, or changes in the associated stromal microenvironment. Studies on a wide spectrum of plant secondary metabolites extractable as natural products from fruits, vegetables, teas, spices, and traditional medicinal herbs show that these plant natural products can act as potent anti-inflammatory, antioxidant or anticancer agents. The recent advances in genomics and metabolomics have enabled biologists to better investigate the potential use of immunomodulatory natural products for treatment or control of various cancerous diseases. The cancer preventive or protective activities of the various immunomodulatory natural products lie in their effects on cellular defenses including detoxifying and antioxidant enzyme systems, and the induction of anti-inflammatory and antitumor or antimetastasis responses, often by targeting specific key transcription factors like nuclear factor kappa B (NF-kB), activator protein (AP-1), signal transducers and activators of transcription (STAT) and others. This review presents recent findings and hypotheses on the molecular mechanisms through which various inflammatory activities are linked to tumorigenic processes and the specific immunomodulatory natural products that may suppress inflammation and the associated tumor progression and metastasis both in vitro and in vivo. In addition to tumor cells per se, the various associated roles of myeloid-derived suppressor cells, stromal fibroblasts, myofibroblasts, and inflammatory immune cells, and the possible effects of phytomedicines on these cells in the tumor microenvironment will be discussed.

\begin{tabular}{|c|c|}
\hline AKT: & $\begin{array}{l}\text { v-akt murine thymoma viral onco- } \\
\text { gene homolog }\end{array}$ \\
\hline AOM: & azoxymethane \\
\hline AP-1: & activator protein-1 \\
\hline ARE: & antioxidant response element \\
\hline CDC: & cell division control \\
\hline CDK: & cyclin-dependent kinase \\
\hline c-FLIP: & cellular FLICE inhibitory protein \\
\hline COX: & cyclooxygenase \\
\hline CREB: & cAMP response element-binding \\
\hline CSF: & colony-stimulating factor \\
\hline DMBA: & dimethylbenz $[a]$ anthracene \\
\hline EGCG: & epigallocatechin gallate \\
\hline EGF: & endothelial growth factor \\
\hline EGFR: & epidermal growth factor receptor \\
\hline ERK: & extracellular signal-regulated kinases \\
\hline FGF: & fibroblast growth factor \\
\hline G-CSF: & granulocyte colony stimulating factor \\
\hline GM-CSF: & $\begin{array}{l}\text { granulocyte macrophage colony-stim- } \\
\text { ulating factor }\end{array}$ \\
\hline GST: & glutathione-S-transferases \\
\hline HIF: & hypoxia inducible factor \\
\hline HPETEs: & hydroperoxyeicosatetraenoic acids \\
\hline I3C: & indole-3-carbinol \\
\hline IAP: & inhibitors of apoptosis \\
\hline iNOS: & inducible nitric oxide synthase \\
\hline JAK: & Janus kinase \\
\hline JNK: & c-Jun NH2-terminal kinase \\
\hline LOX: & lipooxygenase \\
\hline LPS: & lipopolysaccharide \\
\hline MAPK: & mitogen-activated protein kinases \\
\hline MDSCs: & myeloid-derived suppressor cells \\
\hline MMPs: & matrix metalloproteinases \\
\hline NF-KB: & nuclear factor kappa B \\
\hline Nrf2: & $\begin{array}{l}\text { nuclear factor [erythroid-derived 2]- } \\
\text { related factor }\end{array}$ \\
\hline PARP: & poly(ADP-ribose) polymerase \\
\hline PDGF: & platelet-derived growth factor \\
\hline PEITC: & phenylethyl isothiocyanate \\
\hline PI3K: & phosphoinositide 3-kinases \\
\hline
\end{tabular}


ROS:

STAT:

reactive oxygen species

TNF- $\alpha$ :

signal transducers and activators of transcription

TPA:
TRAIL:

VEGF: tumor necrosis factor-related apoptosis-inducing ligand

vascular endothelial growth factor

\section{Introduction}

Recent epidemiological and experimental animal studies strongly suggest that there is a strong link between increased consumption of fruits, vegetables, and certain spices and decreased cancer risk. These foods contain molecules with preventive or protective effects against carcinogenesis caused by irradiation or various endogenous (physiological) and exogenous (environmental or pathogenic) carcinogenic compounds or metabolites [1-4]. The stages of cancer progression have been extensively studied for decades, and carcinogenesis is now recognized as a very dynamic, multifactorial and long-term developmental process, which involves a series of complex factors and signaling systems. The stepwise development of cancer from initiation and promotion is followed by the progression phase, eventually culminating in metastasis that leads to uncontrolled spread of a cancer throughout the body. Although the initiation and promotion steps are evidently important, an increasing body of evidence now suggests that inflammation is a critical component of tumor progression. Many cancers arise from sites of infection, chronic irritation, and inflammation. It is now also becoming clear that the tumor microenvironment, which is largely orchestrated by inflammatory cells, is an indispensable participant in the neoplastic process, fostering proliferation, cell survival, and migration [5-7]. Robert A. Weinberg of the Massachusetts Institute of Technology, highlighted this changing emphasis in a revision of his leading textbook, The Biology of Cancer, noting that "the connection between inflammation and cancer has moved to center stage in the research arena" [8]. Several pro-inflammatory gene products have been identified, which act in concert to mediate a critical role in suppression of apoptosis, proliferation, angiogenesis, invasion, and tumor metastasis. Among these gene products are tumor necrosis factor-alpha (TNF- $\alpha$ ) and other members of its superfamily, interleukin (IL)- $1 \alpha$, IL-1 $\beta$, IL-6, IL-8, IL-18, chemokines (e.g., Mip-3 $\alpha$, CXCL12), matrix metalloproteinases-9 (MMP-9), vascular endothelial growth factor (VEGF), cyclooxygenase-2 (COX-2), and 5-lipooxygenase (5-LOX). The expression of these genes is mainly regulated by the transcription factor $\mathrm{NF}-\mathrm{KB}$, which is constitutively active in most tumors and is readily induced by various chemical carcinogens (e.g., cigarette tars and nicotine), tumor promoters, carcinogenic viral proteins, chemotherapeutic agents, and $\gamma$-irradiation $[1,9]$. Recently, immunologists have observed another class of immunosuppressive cell in cancer patients, the myeloid-derived suppressor cells (MDSCs), a heterogeneous cellular population containing macrophages, granulocytes, immature dendritic cells, and early myeloid precursors [10]. MDSCs, produced under the influence of VEGF, IL-1 $\beta$, and other factors which then migrate into the tumor environment, can inhibit immune responses to the tumor in a number of ways. These include blocking the activities of several types of cells (e.g., dendritic cells) needed for immune responses and converting type 1 macrophages to type 2 [11]. Generally, tumor cells are able to co-opt some of the signaling molecules of the innate immune system, such as cytokines, chemokines, and their receptors, for invasion, migration, and metastasis in the host. The profile of cytokines and chemokines persisting at an inflammatory site is now also known to be very important for the development of chronic disease. Many of the above-mentioned cytokines and chemokines promote inflammation, suggesting that MDSCs may be at least partly responsible for mediating the carcinogenic effects of such inflammation. These insights are fostering new anti-inflammatory therapeutic approaches to the development of anticancer drugs [11-13].

Naturally occurring anti-inflammatory or immunomodulatory plant metabolites, used as single phytochemicals or as crude or fractionated extracts have chemopreventive or therapeutic effects on various cancers, by inducing or suppressing specific cellular inflammatory activities and the associated molecular signaling pathways. Currently, most immunomodulatory agents that are also antitumorigenic belong to two classes, (a) blocking agents, which inhibit the tumor initiation step by preventing carcinogen activation, and (b) suppressing agents, which inhibit tumor cell proliferation during the promotion and metastasis steps of tumorigenesis $[14,15]$. Extensive epidemiological and animal studies have clearly demonstrated that a diet rich in fruits, vegetables, cereal grains, and spices decreases the rate or risk of cancer growth and metastasis [16-18]. Importantly, recent laboratory and preclinical studies have indicated that many of the cellular networks and molecular signaling pathways that act at different stages of carcinogenesis are associated with immune system regulation and inflammatory activities, providing a rationale for the use of immunomodulatory phytochemicals. The immunomodulatory or anti-inflammation effects of these natural products are dependent on dosage, target cell or tissue types and the time course of treatment [19-21]. The differential effects of phytocompounds in tumor cells versus normal cells may be due to different abilities to induce specific apoptotic pathways, modify the levels of major metabolic enzymes, or induce detoxifying enzymes and tumor suppressor genes in different cells [22]. This review discusses recent developments and hypotheses in research on the cancer chemopreventive or chemotherapeutic effects of anti-inflammatory plant natural products, including their effects on signaling pathways or key networks in inflammatory cells.

\section{Blocking Mechanisms of Anti-Inflammatory Plant Natural Products}

The initiation of carcinogenesis can be blocked by anti-inflammatory plant natural products through several different mechanisms. These include prevention of reaction oxygen species (ROS) attack on DNA, alteration of the metabolism of precarcinogens by phase-I drug metabolizing enzymes (so they can no longer be converted to carcinogenic species), excretion of reactive metabolites from the cell by a secondary line of defense that involves phase-II conjugating enzymes [glucuronidases, glutathione-S-transferases (GST) and sulfotransferases], inhibition of uptake of toxic materials into cells, and enhancement of DNA repair. In addition to these specific effects, many anti-inflammatory plant natural products have strong antioxidant effects, either as general antioxidants or free radical scavengers, or by reducing redox imbalance following glutathione depletion. Some natural 
products work by activating protective enzymes (e.g., glutathione peroxidase, superoxide dismutases, heme oxygenases) by targeting the transcription factor nuclear factor [Erythroid-derived 2]-related factor (Nrf2), which activates an antioxidant defense response by an antioxidant response element (ARE) [23, 24]. An effective antioxidant defense response in the face of a mild redox stress seems to be cytoprotective for normal or untransformed cells, probably because it can successfully counteract the genotoxic damage resulting from oxidative and electrophilic stress, and detoxifies excessive ROS [4]. Some of these anti-inflammatory plant secondary metabolites with high antioxidant activities, for example, resveratrol (a polyphenol from grapes), genistein (an isoflavone in soybean), quercetin (a flavonol in vegetables and fruits), shikonin (a naphthoquinone from Lithospermum erythrorhizon) and others are presented in $\bullet$ Table 1. Blocking the initial genetic modification step of carcinogenesis by the consumption of various anti-inflammatory plant natural products helps to prevent the development of primary tumors $[4,25]$.

Paradoxically, some immunomodulatory plant natural products, such as epigallocatechin gallate (EGCG) in green tea, the polyphenol curcumin in turmeric and ascorbic acid in fruits, can act as both oxidants and antioxidants $[4,25]$. Significant blockade and modulation of the phase I and phase II enzymes in human liver cancer cells by quercetin [26] and resveratrol [27] can be observed as either antioxidant or prooxidant activities under different experimental/physiological conditions and cancer cell types. Curcumin possesses potent anti-inflammatory activities and is a strong activator of Nrf2-protein and detoxifying heme-oxygenases in human cells [28]. Shikonin has strong antioxidant and anti-inflammatory activities via inhibition of TNF- $\alpha$, granulocyte macrophage colony-stimulating factor (GM-CSF) $[29,30]$, presumably also via phase-II enzymes. EGCG and sulforaphane from cruciferous vegetables induce Nrf2 transcription factor, and eventually activate the antioxidant defense enzymes by ARE [31].

\section{The Suppression Mechanisms of Anti-Inflammatory Plant Natural Products \\ $\nabla$}

Growth suppression of tumor cells can be observed either as the induction of cell cycle arrest, which slows down inappropriate or uncontrolled cell division, or as the induction of apoptosis in stressed cells. Some anti-inflammatory plant natural products have been found to be very effective regulators of the cell cycle of tumor cells at an early stage by targeting specific cell signaling molecules, leading to apoptosis or cellular senescence. Other plant secondary metabolites can act at later stages of tumorigenesis by inhibition of angiogenesis or prevention of tumor invasion and metastasis [32-34]. Many anti-inflammatory plant natural products have molecular signaling targets that can be potentially employed for treatment of cancers. A main feature of a number of anti-inflammatory plant natural products (e.g., EGCG, curcumin, lycopene, gingerol and resveratrol) is their action on the suppression of EGFR and the subsequent downregulation of expression of various other key signaling molecules such as STAT- $1,-3$, NF-KB, AKT, Bcl-2 in the nucleus and/or cytoplasm, which eventually induces apoptosis of target cells. The signaling network diagram ( $\bullet$ Fig. 1) summarizes all these recent findings and specific categories of these interactions are discussed below.

\section{Cell cycle}

Effective disruption of cell cycle progression and division of tumor cells by antitumor agents is very important for inhibition of cancer growth. The anti-cell cycle effects of several anti-inflammatory plant natural products have been extensively studied. Indole-3-carbinol (I3C) induces $\mathrm{G}_{0}-\mathrm{G}_{1}$ cell cycle arrest in breast cancer cells through downregulation of cyclin-dependent kinase 6 (CDK6); it upregulates the CDK inhibitors p21 and p27 [35]. Proanthocyanidins from grape seed produce a marked reduction in expression of CDK2, CDK4, and CDK6, and of cyclins D1, D2, and $\mathrm{E}$ in human epidermoid carcinoma (A431) cells [36]. Resveratrol causes cell cycle arrest mainly by upregulating the expression of p21, p27, and p16 and downregulating cyclin D1, E, CDK2, CDK4, and CDK7 in human colon carcinoma cells [37]. Amooranin (AMR), a novel triterpenoid from Amoora rohituka suppresses G2/M phase and inhibits the growth of MCF-7 and MDA-468 breast cancer cells [38], while geraniol (an isoprenoid) inhibits CDK2 expression in human pancreatic adenocarcinoma cells, apparently mediated by a p21/p27-dependent pathway [39]. Curcumin induces $G_{0} / G_{1}$ and/or $G_{2} / M$ phase cell cycle arrest, upregulates CDK inhibitors such as p21/Cip1/waf1 and p27Kip1, and downregulates cyclin B1 and cell division control 2 (CDC2) in immortalized human umbilical vein endothelial (ECV304) cells [40]. Similarly, EGCG induces cell cycle arrest by upregulation of p21/Cip1/waf1 and p27Kip1 and the subsequent downregulation of cyclin D1, cyclin E, CDK2 and CDK4 in human prostate carcinoma cells [41].

\section{Cell survival and proliferation}

Elevated signaling from mitogen-activated protein kinases (MAPK), phosphoinositide 3-kinases (PI3K), protein kinase B (PKB), AP-1 and NF-KB often favors cell survival and proliferation. Most of the key molecular targets in these pathways have been found to be overexpressed or constitutively upregulated in a variety of cancers, strongly suggesting that inhibition of these molecular targets can induce tumor cells to undergo apoptosis. Sulforaphane, an isothiocyanate from many crucifers, can suppress the phosphorylation of c-Jun NH2-terminal kinase (JNK), extracellular signal-regulated kinases (ERK) and v-akt murine thymoma viral oncogene homolog (AKT) of gastrointestinal cancers and inhibit tumor growth [42]. Proanthocyanidins from grape seeds suppress NF-KB of human epidermoid carcinoma A431 cells by downregulation of NF-KB/p65 and IKK $\alpha$, and inhibit the degradation of IKB $\alpha$ protein, which is a regulator of NF-кB [36]. Proanthocyanidins also inhibit the constitutive activation of MAPK proteins and decrease the phosphorylation of AKT in A431 cells [36]. EGCG inhibits the PI3K/AKT signaling pathways, thereby inducing apoptosis by suppressing Bcl-2 family protein expression and increasing Bax protein expression in T24 human bladder cancer cells [43]. Phenylethyl isothiocyanate (PEITC), another component of cruciferous vegetables, potently inhibits NF-кB by inhibiting IKK $\alpha / \beta$ signaling pathways in human prostate cancer cells [44]. Curcumin was suggested to mediate therapeutic effects in test animals by regulating the transcription factor NF- $\mathrm{KB}$ and NF-KB-regulated gene products such as cyclin D1, Bcl-2, Bcl-xL, and TNF- $\alpha$ [45]. Curcumin suppresses TNF- $\alpha$ induced IKK $\alpha$ which leads to the inhibition of TNF-dependent phosphorylation and degradation of IKB $\alpha$ protein and thus can suppress the activation of NF-KB [46]. Curcumin also suppresses the activation of 12-Otetradecanoylphorbol 13-acetate (TPA)-induced activator protein (AP-1) in HL-60 cells [47] and prostate cancer cells [48]. Genistein, an isoflavone from soybean, significantly suppresses human 
Table 1 Dietary source, mechanism of action and molecular targets of natural compounds.

\begin{tabular}{|c|c|c|c|c|c|}
\hline Group & Compound & Dietary source & Mechanism of action & Molecular targets & Reference \\
\hline Isothiocyanates & $\begin{array}{l}\text { Sulforaphane, Phenethyl } \\
\text { isothiocyanate, Benzyl } \\
\text { isothiocyanate }\end{array}$ & $\begin{array}{l}\text { crucifereous vegetables } \\
\text { (all Brassicacea), cab- } \\
\text { bage, broccoli, turnips, } \\
\text { cauliflower, brussels } \\
\text { sprouts, kale, mustard, } \\
\text { cress, etc. }\end{array}$ & $\begin{array}{l}\text { anti-inflammation, anti- } \\
\text { proliferation, activation } \\
\text { of caspases, inhibition of } \\
\text { angiogenesis }\end{array}$ & $\begin{array}{l}\text { AKT, NF-KB, AP-1, Bcl2, } \\
\text { survivin, cyclin D, CDK, } \\
\text { p53, Bax, COX-2, iNOS, } \\
\text { VEGF, MMP-2/-9 }\end{array}$ & $\begin{array}{l}{[58,91,135,} \\
155,156]\end{array}$ \\
\hline Proanthocyanidins & $\begin{array}{l}\text { Proanthocyanidins A2, } \\
-B 1,-C 1 \text {. }\end{array}$ & $\begin{array}{l}\text { cocoa, berries, beans, } \\
\text { nuts, wine }\end{array}$ & $\begin{array}{l}\text { antioxidant, cell cycle } \\
\text { arrest, anti-inflammation }\end{array}$ & $\begin{array}{l}\text { MAPK, PI3K/AKT, NF-KB, } \\
\text { MMP-2, -9, AP-1, iNOS, } \\
\text { COX-2 }\end{array}$ & $\begin{array}{l}{[15,157-} \\
159]\end{array}$ \\
\hline \multirow[t]{6}{*}{ Flavonoids } & Quercetin & $\begin{array}{l}\text { onion, broccoli, apples } \\
\text { and berries }\end{array}$ & $\begin{array}{l}\text { anti-inflammatory and } \\
\text { apoptosis }\end{array}$ & $\begin{array}{l}\text { iNOS, COX-2, AKT, } \\
\text { caspases }\end{array}$ & {$[160,161]$} \\
\hline & Apigenin & celery and parsley & $\begin{array}{l}\text { cell cycle arrest and } \\
\text { apoptosis }\end{array}$ & $\begin{array}{l}\text { CDK, caspases, Bax, p53, } \\
\text { p21 }\end{array}$ & {$[162,163]$} \\
\hline & Tangeretin & citrus peel & $\begin{array}{l}\text { anti-inflammatory and } \\
\text { cell cycle arrest }\end{array}$ & $\begin{array}{l}\text { ERK, AKT, NF-KB, AP-1, } \\
\text { cyclin D1, CDK, iNOS, } \\
\text { COX-2 }\end{array}$ & {$[92,164]$} \\
\hline & $\begin{array}{l}\text { Epigallocatechin-gallate } \\
\text { (EGCG) }\end{array}$ & tea & $\begin{array}{l}\text { antioxidant, antimuta- } \\
\text { genesis, antiprolifera- } \\
\text { tion, antiangiogenesis, } \\
\text { anti-inflammation }\end{array}$ & $\begin{array}{l}\text { EGFR, AKT, NF-kB, cyclin } \\
\text { D1, VEGF, COX-2, AP-1, } \\
\text { MMP-2/-9, Bcl-2, Bax, } \\
\text { IL-12 }\end{array}$ & $\begin{array}{l}{[60,62,130,} \\
165,166]\end{array}$ \\
\hline & Genistein & soybeans, red clover & $\begin{array}{l}\text { antiproliferation, antioxi- } \\
\text { dant, antiangiogenesis, } \\
\text { anti-inflammation }\end{array}$ & $\begin{array}{l}\text { caspases, ASK-1, AKT, } \\
\text { NF-kB, survivin, Bcl-2, } \\
\text { Bax, STAT-3/-5, CDK, } \\
\text { VEGF }\end{array}$ & $\begin{array}{l}{[72,167,} \\
168]\end{array}$ \\
\hline & Delpinidin & $\begin{array}{l}\text { pomegranate, } \\
\text { strawberry }\end{array}$ & $\begin{array}{l}\text { apoptosis, antioxidant, } \\
\text { antiangiogenesis }\end{array}$ & $\begin{array}{l}\text { AP-1, NF-kB, C/EBPס, } \\
\text { MMP-2/-9, VEGF, } \\
\text { caspases, Bcl-2, Bax }\end{array}$ & {$[74,169]$} \\
\hline Flavonolignans & Silibinin & milk thistle & $\begin{array}{l}\text { anti-inflammation, cell } \\
\text { cycle arrest, apoptosis }\end{array}$ & $\begin{array}{l}\text { STAT-3, NF-KB, JNK, } \\
\text { CDK, iNOS, COX-2, } \\
\text { MAPK, AKT, Bax, Bcl-2 }\end{array}$ & {$[21,170]$} \\
\hline \multirow[t]{4}{*}{ Carotenoids } & Zeaxanthin & peas, cabbage, orange & $\begin{array}{l}\text { antioxidant, anti-inflam- } \\
\text { mation, apoptosis }\end{array}$ & $\begin{array}{l}\text { iNOS, COX-2, AKT, } \\
\text { Bax, Bcl-2, caspases }\end{array}$ & {$[171,172]$} \\
\hline & Lycopene & tomato, orange, papaya & $\begin{array}{l}\text { antiproliferation, antioxi- } \\
\text { dant, antiangiogenesis, } \\
\text { anti-inflammation, im- } \\
\text { munomodulator }\end{array}$ & $\begin{array}{l}\text { Bcl-2, Bcl--xL, Bax, p53, } \\
\text { caspases, cyclin D1, } \\
\text { AKT, NF-kB, MMP-9, BAD, } \\
\text { Sp-1, cytochrome c, } \\
\text { IGF-BP3, PCNA }\end{array}$ & [173-175] \\
\hline & $\beta$-Carotene & $\begin{array}{l}\text { carrots, pumpkin, } \\
\text { green leafy vegetables, } \\
\text { red palm oil }\end{array}$ & $\begin{array}{l}\text { antioxidant, anti-inflam- } \\
\text { mation, apoptosis }\end{array}$ & $\begin{array}{l}\text { AKT, NF-kB, iNOS, } \\
\text { COX-2, caspases, Bax, } \\
\text { BCl-2, GSH }\end{array}$ & {$[176,177]$} \\
\hline & Lutein & spinach & $\begin{array}{l}\text { antiangiogenesis, anti- } \\
\text { oxidant, apoptosis }\end{array}$ & $\begin{array}{l}\text { VEGF, AP-1, NF-kB, } \\
\text { C/EBPס, MMP-2/-9, } \\
\text { caspases, Bcl-2, Bax }\end{array}$ & [178] \\
\hline Terpenoids & Geranoil, limonene & citrus, cherries, grapes & $\begin{array}{l}\text { apoptosis, cell cycle } \\
\text { arrest, anti-inflamma- } \\
\text { tion, antiangiogenesis }\end{array}$ & $\begin{array}{l}\text { TNF- } \alpha, \text { Bcl-2, Bcl-xL, Bax, } \\
\text { p53, caspases, cyclin D1, } \\
\text { CDK, p21, p27, VEGF }\end{array}$ & {$[39,179]$} \\
\hline \multirow[t]{3}{*}{ Polyphenols } & Curcumin & turmeric & $\begin{array}{l}\text { antiproliferation, antioxi- } \\
\text { dant, anti-inflammation, } \\
\text { antiangiogenesis, immu- } \\
\text { nomodulation }\end{array}$ & $\begin{array}{l}\text { AKT, EGFR, Her2, NF-kB, } \\
\text { IGF-1R, Bcl-2, COX-2, } \\
\text { ERK, AP-1, VEGF, MMP-2/ } \\
-9, \text { p53, p21, Bax, } \\
\text { STAT-3/-5, survivin, iNOS }\end{array}$ & $\begin{array}{l}{[68,108,} \\
180]\end{array}$ \\
\hline & Resveratrol & grapes & $\begin{array}{l}\text { antiproliferation, antioxi- } \\
\text { dant, anti-inflammation, } \\
\text { antiangiogenesis }\end{array}$ & $\begin{array}{l}\text { NF-kB, iNOS, COX-2, } \\
\text { STAT-3, p53, survivin, } \\
\text { p53, p21, Bax, SOD, } \\
\text { catalase, GSH, cyclin D1, } \\
\text { CDK, VEGF }\end{array}$ & {$[181,182]$} \\
\hline & 6-Gingerol & ginger & $\begin{array}{l}\text { antioxidant, anti-inflam- } \\
\text { mation, antiprolifera- } \\
\text { tion, antiangiogenesis }\end{array}$ & $\begin{array}{l}\text { GSK-3ß, MMP-2/-9, VEGF, } \\
\text { NF-KB, AP-1, COX-2, } \\
\text { iNOS, Bax, Bcl-2, CDK, } \\
\text { cyclin D1, cytochrome c, } \\
\text { caspases }\end{array}$ & {$[132,183]$} \\
\hline Glucosinolate & Indole-3-carbinol & cruciferous vegetables & $\begin{array}{l}\text { antiproliferation, anti- } \\
\text { angiogenesis }\end{array}$ & $\begin{array}{l}\text { NF-KB, PI3K, AKT, Bcl-2, } \\
\text { Bax, BCl-xL, caspases, } \\
\text { TRAIL, cFLIP, IAP }\end{array}$ & $\begin{array}{l}{[184,185]} \\
\text { continued }\end{array}$ \\
\hline
\end{tabular}


Table 1 Continued

\begin{tabular}{|c|c|c|c|c|c|}
\hline Group & Compound & Dietary source & Mechanism of action & Molecular targets & Reference \\
\hline $\begin{array}{l}\text { Organosulfur } \\
\text { compounds }\end{array}$ & $\begin{array}{l}\text { Allicin, diallyl sulfide } \\
\text { (DAS), S-allylcysteine }\end{array}$ & garlic and onion & $\begin{array}{l}\text { antiproliferation, anti- } \\
\text { angiogenesis, anti- } \\
\text { inflammation, immuno- } \\
\text { modulation }\end{array}$ & $\begin{array}{l}\text { JNK, caspases, PARP, } \\
\text { Bax, Bcl-2, VEGF, p38, } \\
\text { cytochrome c, p53 }\end{array}$ & [186] \\
\hline $\begin{array}{l}n-3 \text { Polyunsaturated } \\
\text { fatty acids (PUFAs) }\end{array}$ & & $\begin{array}{l}\text { sunflower oil, corn oil, } \\
\text { safflower oil, olive oil }\end{array}$ & $\begin{array}{l}\text { apoptosis, anti-inflam- } \\
\text { mation, cell cycle arrest }\end{array}$ & $\begin{array}{l}\text { NF-kB, Bax, Bcl-2, STAT-3, } \\
\text { Fas/FasL, Ras, ERK 1/2, } \\
\text { p53, cyclin D1, CDK, } \\
\text { COX-2 }\end{array}$ & [187] \\
\hline
\end{tabular}

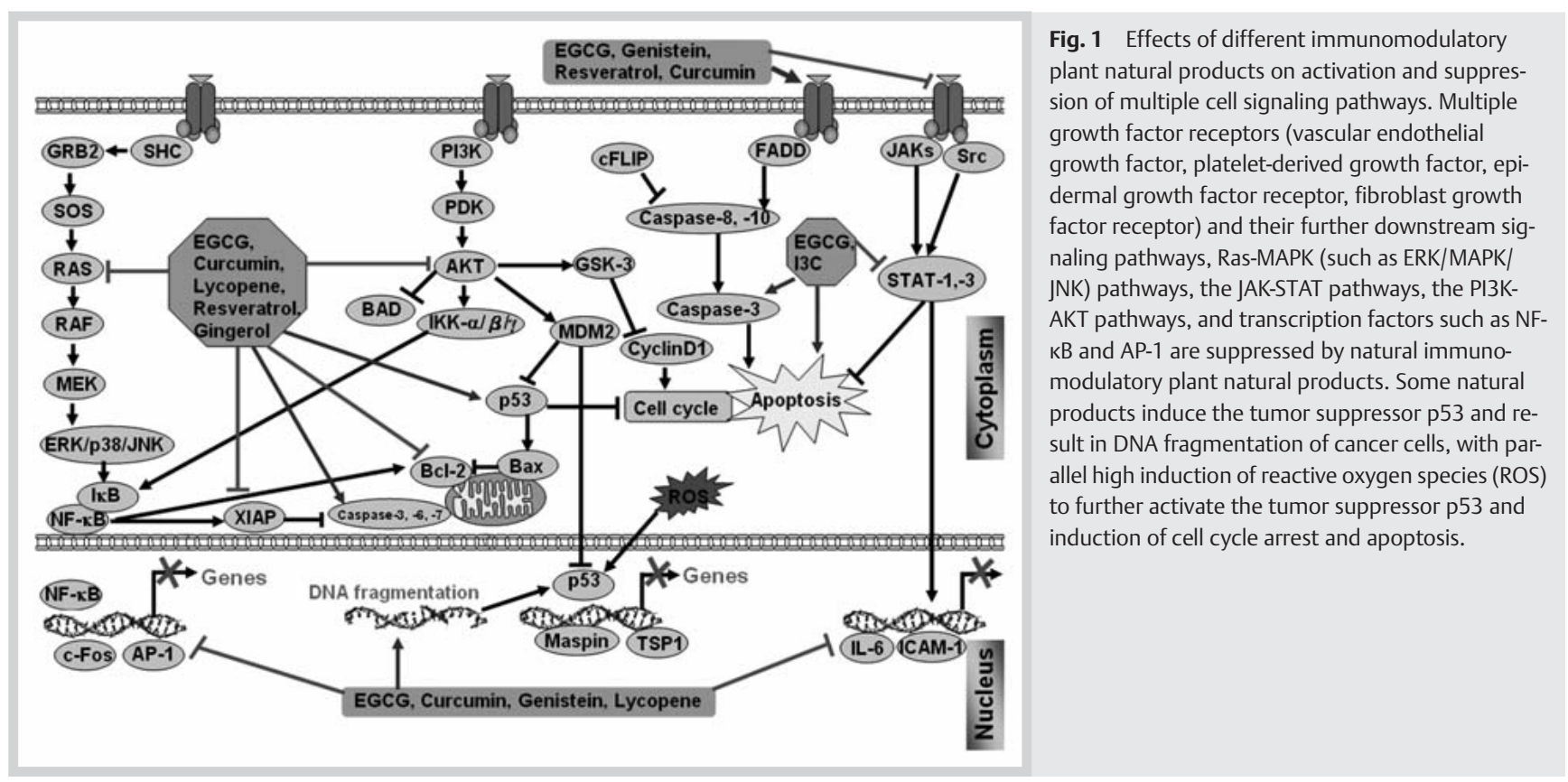

bladder cancer growth and induces apoptosis through inhibition of the NF-KB pathway [49]. [6]-Gingerol, a phenolic substance from ginger root (Zingiber officinale), inhibits epidermal growth factor-induced AP-1 activation and neoplastic transformation in mouse epidermal JB6 cells [50]. Capsaicin, the pungent component of hot chili (Capsicum annuum), suppresses TNF- $\alpha$ induced AP-1 activation in cultured human leukemia HL-60 cells, resulting in inhibition of cell survival and proliferation [51]. I3C inhibits the activation of AKT and NF-KB of breast cancer cells, downregulates their specific target gene products including cyclin D1 and E, and induces apoptosis of breast cancer cells [52]. Resveratrol blocks NF-KB activation and significantly inhibits the activities of MAPK/ERK kinase (MEK) and JNK and the binding efficiency of AP-1 to DNA in human lymphoma cells [53]. The inhibitory activities of various phytochemicals toward specific pro-inflammatory signaling activities collectively describe a relatively common molecular mechanism for their antitumor actions.

\section{Apoptosis \\ $\nabla$}

Apoptosis is a specific, programmed mechanism of cell death that helps to regulate tissue homeostasis through the elimination of populations of potentially deleterious cells [54]. This activity involves the active participation of affected cells in a self-destruc- tion cascade that includes symptoms of membrane blebbing, shrinkage of cell and nuclear volume, chromatin condensation and endonuclease activation-mediated nuclear DNA fragmentation [55]. Many studies have suggested that various anti-inflammatory plant natural products ( $\odot$ Fig. 2 a, b) may work by induction of apoptosis in cancer cells and subsequently suppress tumor growth. Resveratrol effectively induces apoptosis in rat and human cancer cells. The resveratrol-induced apoptosis in human cancer cells was reported mainly to result from an increase in caspase activity, upregulation of p53, Bax, and downregulation of Bcl-2, Bcl-XL, survivin and inhibitors of apoptosis (IAPs) in a variety of human cancers $[56,57]$. Benzyl isothiocyanate, yet another component of cruciferous vegetables, causes apoptosis by inducing DNA damage in human pancreatic cancer cells [58]. I3C, also abundant in cruciferous vegetables, induces apoptosis by significant downregulation of Bcl-2, Bcl-XL, IAP, X chromosome-linked IAP, and cellular FLICE inhibitory protein (c-FLIP) in human prostate cancer cells [59]. In treating pancreatic cells, EGCG invokes Bax oligomerization and depolarization of mitochondrial membranes to enhance release of cytochrome $c$ into cytosol. EGCG also induces downregulation of X chromosomelinked IAP to facilitate cytochrome $c$-mediated downstream caspase activation [60]. In prostate cancer cells, EGCG treatment causes an activation of caspases-3, -7 , and -9 , followed by upregulation of Bax and downregulation of $\mathrm{Bcl}-2$ proteins, eventually 
<smiles>Oc1ccc(CC=C2CCC(O)CC2)cc1O</smiles>

Resveratrol<smiles>Oc1ccc(C2COCC3C(O)CC(O)C3C2O)cc1</smiles>

Genistein<smiles>O=C1C(O)C2C(O)CC(O)CC2OC1C1CCC(O)C(O)C1</smiles>

Quercetin

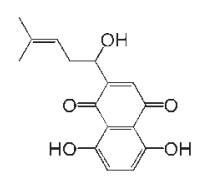

Shikonin<smiles>O=C(OC1CC(O)C(O)CC1C(=O)O)C1CC(O)C(O)C(O)C1</smiles>

Epigallocatechin gallate<smiles>COc1cc(CCC(O)CC(O)CCC2CCC(O)C(O)C2)ccc1O</smiles>

Curcumin<smiles>CCC(C)CCCCCCC(O)NCC1CCC(O)C(OC)C1</smiles>

Capsaicin<smiles>OC1OC(O)C(O)C1O</smiles>

Ascorbic acid<smiles>CCNCC1CCCCC1CO</smiles>

Indole-3-carbinol

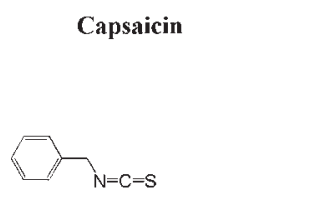

Benzyl isothiocyanate<smiles>CC(C)CCCC(C)CCO</smiles>

Geraniol

Luteolin<smiles>OC1CC(O)C(C2C(O)CC3CC(O)C(O)CC3CC2O)CC1O</smiles><smiles></smiles>

Sulforaphane Delphinidin

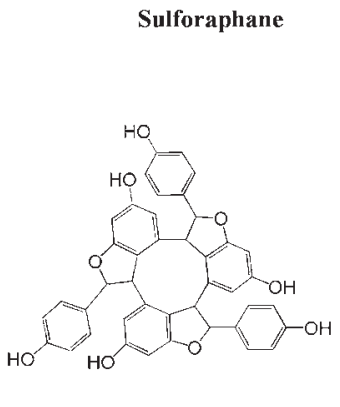

a

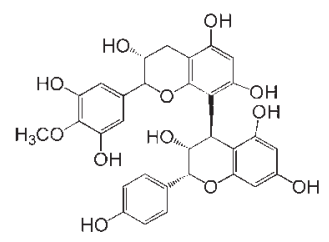

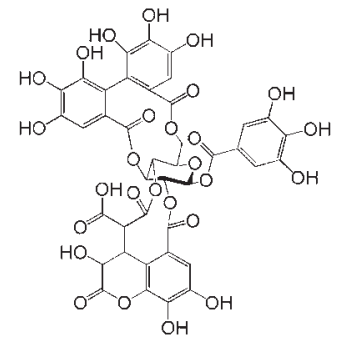

Chebulagic acid
Fig. 2a Chemical structures of anti-inflammatory plant natural products. leading to apoptosis [61]. EGCG treatment also results in downregulation of anti-apoptotic protein $\mathrm{Bcl}-2$ and upregulation of pro-apoptotic Bax in melanoma cells [62], and increased tumor necrosis factor-related apoptosis-inducing ligand (TRAIL)-induced apoptosis in hepatocellular carcinoma cell lines [63]. Luteolin, abundant in celery and green pepper, induces the expression of TRAIL and Bid, leading to cleavage and activation of caspases-8, -10, -9 and -3 , and subsequent apoptosis in HeLa cells [64]. Apigenin, a flavonoid from parsley, celery and lettuce, induces apoptosis in monocytic and lymphocytic leukemia cell lines, and this was reported to be mediated by activation of caspase- 9 and -3 and of PKC $\Delta$ [65]. Curcumin induces apoptosis in human melanoma cells through activation of a Fas receptor/caspase-8 pathway [66], but paradoxically can inhibit the mitochondrial release of cytochrome $c$ in human breast cancer cell lines [67]. Curcumin differentially sensitizes malignant glioma cells to TRAIL/ Apo2L-mediated apoptosis through activation of procaspases and release of cytochrome $c$ from mitochondria [68]. The organosulfur compound diallyl sulfide, a natural immunomodulatory plant natural product from onion and garlic, induces apoptosis via mitochondria-mediated cell death in prostate cancer cells, regulated by Bax/Bak but independent of $\mathrm{Bcl}-2$ or $\mathrm{Bcl}-\mathrm{xL}^{\mathrm{L}}$ [69]. Allicin induces apoptosis in human epithelial carcinoma cells, mediated by mitochondrial release of apoptosis inducing factor (AIF) [70]. Genistein, the soy isoflavone, decreases anti-apoptotic Bcl-2 protein and increases pro-apoptotic Bax protein, and leads to apoptosis of human gastric cancer cells [71]. In hepatocellular carcinoma cells, genistein treatment leads to activation of caspase-3, and -9 , and cleavage of the caspase- 3 substrate, poly (ADP-ribose) polymerase (PARP) [72] and enhanced TRAIL-induced apoptosis through inhibition of p38 MAPK [73]. Delphinidin, a flavonoid metabolite in depigmented fruits, activates caspases, increases Bax, Bid, and Bak levels, and decreases Bcl-2 and $\mathrm{Bcl}-\mathrm{x}_{\mathrm{L}}$ levels in immortalized human keratinocyte $\mathrm{HaCaT}$ cells [74]. 


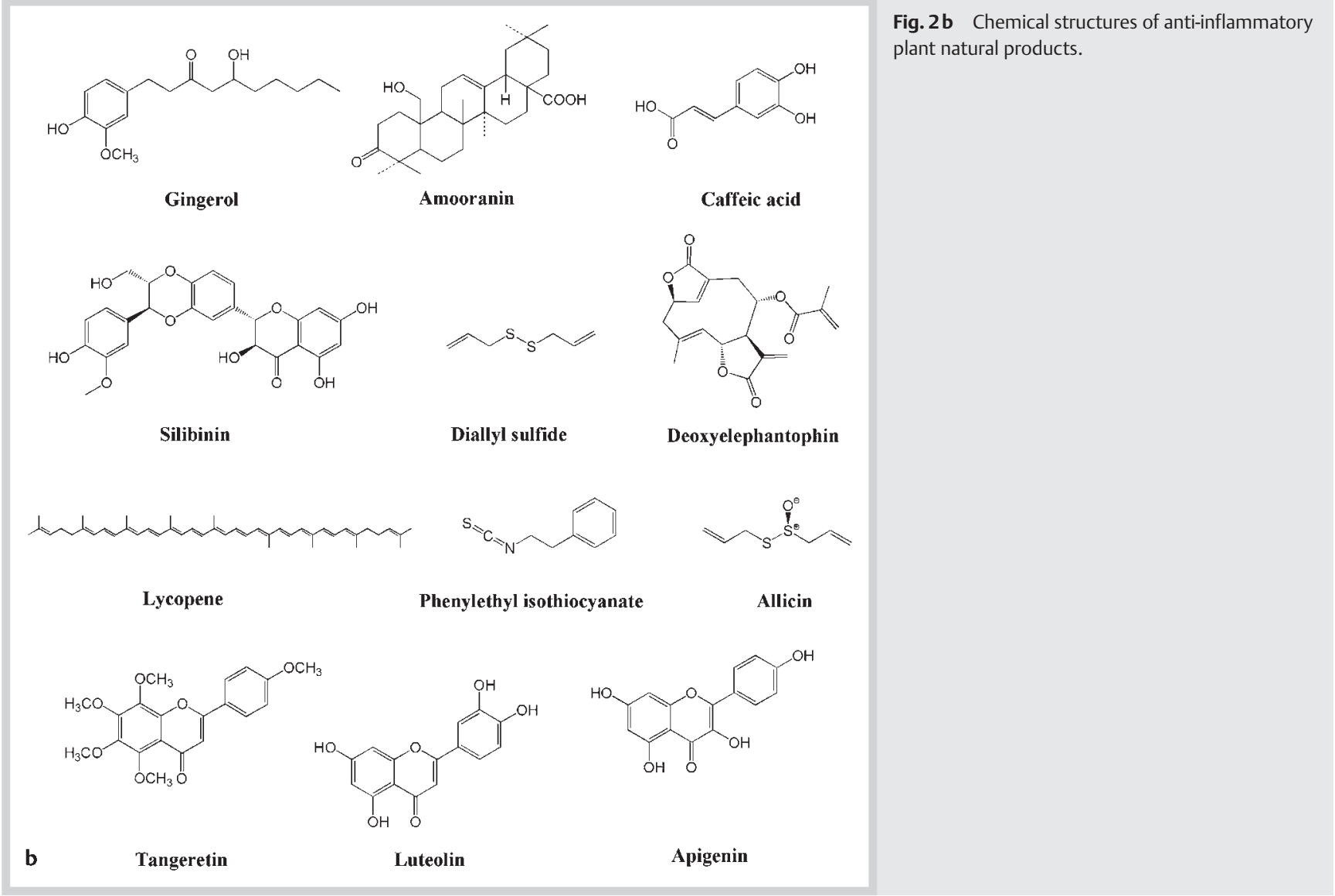

\section{Inflammation}

$\nabla$

Inflammation can be a host response to invading foreign pathogens, a reaction to tissue injury, or a response to a spectrum of physical, chemical, or biological stresses. Inflammatory responses are often induced by tissue wounding, and eventually lead to the restoration of normal structure and function of tissues by wound healing. A normal inflammatory response is generally self-limiting, and involves the eventual downregulation of expression of various pro-inflammatory proteins (some of the cytokines and chemokines) and increased expression of a group of anti-inflammatory proteins (other specific cytokines and chemokines) $[75,76]$. NF-KB, a key molecule for many inflammatory responses, is a dimeric transcription factor that is formed by the dimerization of specific proteins of the Rel family [77]. The activity of NF-KB is fine tuned by various inflammatory stress or danger signals, and it is responsible for the hierarchical regulation of the expression of a spectrum of genes that encode inflammatory cytokines, chemokines, adhesion molecules, growth factors, and inducible enzymes such as COX-2 and inducible nitric oxide synthase (iNOS) [77,78]. In addition to NF-KB, another important inflammatory modulator that is being examined as a target in cancer is TNF- $\alpha$, a growth factor or promoter for most tumor cells, now recognized to play a very important role in the maintenance of tumorigenesis [79]. Various immunomodulatory plant secondary metabolites such as EGCG, curcumin and resveratrol have been shown to decrease TNF- $\alpha$ production in tumor cells and thereby suppress tumor growth [80-82].

The two most accessible inducible pro-inflammatory enzymes in cancer therapy are iNOS and COX-2. The expression of both COX-
2 and iNOS is tightly regulated, and may be readily induced by oxidative stress and certain inflammatory cytokines. They are thus suggested to play an important role in the promotion and progression of various cancers. In fact, the $5^{\prime}$ promoter regions of both iNOS and COX-2 genes contain putative binding sites for the transcription factors NF-KB and AP-1 $[83,84]$. COX is an essential enzyme in arachidonic acid metabolism, which can be divided into the LOX or the COX pathways. The COX pathway leads to prostaglandin (PG) and thromboxane production, whereas the LOX pathway leads to synthesis of leukotrienes (LTs) and hydroperoxyeicosatetraenoic acids (HPETEs). There are two main enzymes in the COX pathway, COX-1 and COX-2, and of these, COX2 plays the major role in inflammation, including activities associated with cell growth regulation, tissue remodeling and carcinogenesis [85]. Overexpression of COX-2 results in induction of pro-inflammatory PGs such as prostaglandin E2 (PGE2), antiapoptotic Bcl-2 family proteins, E-cadherin, MMPs, and specific angiogenic factors, and activation of the antiapoptotic PI3K/AKT pathway $[86,87]$. EGCG selectively inhibited the expression of COX-2 and cell growth in human prostate carcinoma cells [88]. It also downregulated COX-2 activity in TPA-stimulated human mammary MCF-10A cells in vitro [89]. The important anti-inflammatory curcumin inhibited COX-2 activities through suppression of NF-KB activity via control of the NIK/IKK signaling complex in colon cancer cells [90]. Sulforaphane suppressed lipopolysaccharide (LPS)-induced COX-2 expression and downregulated NF-KB, сAMP response element-binding (CREB) and AP-1 activities [91]. Tangeretin, a flavonoid in citrus peels, was reported to effectively suppress IL- $1 \beta$-induced COX- 2 expression through inhibition of p38 MAPK and JNK, and activation of AKT in 
human lung carcinoma cells [92]. Another flavonoid, delphinidin, abundant in dark fruits, significantly inhibited COX-2 expression by blocking MAPK signaling and NF-KB, AP-1 and C/EBPS nuclear translocation in LPS-stimulated murine macrophage RAW264.7 cells [93]. Similarly, the grape phytocompounds resveratrol and $\alpha$-viniferin inhibited COX-2 activity and COX-2 mRNA transcription in the same cell type [94].

There are several reports that immunomodulatory plant natural products can specifically suppress 5-LOX activity. Curcumin inhibited the release of arachidonic acid, cytosolic phospholipase A2 (cPLA2) and 5-LOX in LPS-stimulated RAW cells and A23187stimulated human colon cancer HT-29 cells [95]. EGCG can significantly suppress the 5-LOX-dependent metabolism of arachidonic acid in human colon mucosa and colon tumor tissues [96]. Chebulagic acid (CA), a natural antioxidant, showed potent antiinflammatory effects in suppression of 5-LOX in stimulated macrophages [97]. Procyanidins from cocoa (Theobroma cocoa) significantly inhibited the activity of human 5-LOX, a key enzyme for synthesis of pro-inflammatory leukotrienes, and suppressed inflammatory activities [98].

A number of naturally-occurring inhibitors of iNOS are being evaluated in clinical trials for cancer prevention. Curcumin has been reported to exert strong inhibitory effects on iNOS and its upstream regulators. Low concentrations of curcumin inhibited NO production via suppression of iNOS mRNA transcription and protein expression in macrophages [99]. Similarly, EGCG was found to inhibit expression and catalytic activities of iNOS, reduce the DNA binding ability of NF-KB and inhibit the transcriptional activity of AP-1 [1]. Phenylethyl isothiocyanate in winter cress showed a strong anti-inflammatory activity by reducing the level of iNOS mRNA in LPS-stimulated mouse RAW264.7 macrophages [100]. Gingerol of ginger inhibited nitric oxide synthesis in activated J774.1 mouse macrophages and prevented peroxynitrite-induced oxidation and nitration reactions in macrophages [101]. I3C from cruciferous vegetables reduced the level of iNOS in stimulated macrophages [102].

\section{Signal Transducers and Activators of Transcription (STAT) Pathway}

One of the key signal transduction pathways to the nucleus has been discovered through the study of transcriptional activation in response to interferon-gamma (IFN- $\gamma$ ) [103]. So far, cDNA genes encoding seven mammalian STAT family members (STAT1-7) have been cloned, and found to share some common structural elements. These STAT family members can be activated by phosphorylation through specific cytokine receptors, e.g., by Janus kinase (JAK), growth factor receptors and various G-protein-coupled receptors, which can lead to the dimerization and nuclear localization of targeted STAT proteins, resulting in binding to specific DNA elements and ultimately activating the transcription of specific targeted genes. Importantly, constitutive activation of STAT3 and STAT5 has been implicated in many solid tumors, especially lymphomas and leukemias, among others [104-106]. A number of anti-inflammatory plant secondary metabolites have been shown to suppress gene activation of members of the STAT family in tumor cells. Polyphenols from green tea inhibit STAT3 expression and prostate cancer growth and subsequently induce apoptosis of prostate cancer cells [107]. In Hodgkin's lymphoma cells, curcumin induces cell arrest and apoptosis in association with the inhibition of the constitutively active NF-KB and STAT3 pathways. Its expression in the human chronic myelogenous leukemia cell line K562 also induces a decrease of nuclear STAT3, $-5 a$ and $-5 b$, without affecting either STAT1 expression or the phosphorylation states of STAT1, -3 or -5 [108]. Most interestingly, the decrease of nuclear STAT5a and $-5 b$ after curcumin treatment was accompanied by an increase of the truncated STAT5 isoforms, indicating that curcumin is able to induce the cleavage of STAT5 into its dominant negative variants lacking the STAT5 C-terminal region [109]. Resveratrol modulates IL-6-induced intercellular adhesion molecule-1 (ICAM-1) gene expression by suppressing STAT3 phosphorylation [110]. Luteolin, a flavonoid from celery and green pepper, promotes degradation of STAT3 in human hepatoma cells, leading to a downregulation of the targeted downstream gene products such as cyclin D1, survivin, and Bcl-xL [111]. Another flavonoid, kaempferol, found in broccoli and tea, significantly inhibits STAT1 and NF-KB activation in LPS-activated murine macrophage J774 cells [112]. Silibinin, a flavonolignan in milk thistle extract, inhibits the activation of STAT3 in human bladder cancer DU145 cells and suppresses tumor growth both in vitro and in vivo. Silibinin robustly decreases the protein expression and nuclear localization of survivin, as well as its secretion from tumor into plasma in the mouse, but it also increases the levels of p53 and cleaved caspase- 3 in test tumors [21]. Many of these findings suggest that immunomodulatory and anti-inflammatory plant natural products target the STAT-signaling pathways, and can result in effective suppression of tumor growth (๑ Fig. 1).

\section{Growth factors and their receptors}

Growth factors are proteins, steroids or other biochemical substances that can bind to specific receptors on the cell surface, and thereby, via a cascade signaling pathway or network, stimulate the proliferation and differentiation of targeted cells or tissues. Growth factors can act as signaling molecules between two different cell types, and are important for regulating a variety of cellular processes. A number of growth factor signaling molecules, such as fibroblast growth factor (FGF), endothelial growth factor (EGF), platelet-derived growth factor (PDGF), insulin-like growth factor (IGF), hepatoma-derived growth factor, hypoxiainducible factor, VEGF, IL-1, IL-6, IL-8, IL-10, colony-stimulating factor (CSF), and transforming growth factor (TGF) play important roles in carcinogenesis and metastasis. Activation of abnormal growth factor signaling pathways leads to increased cell proliferation, differentiation, maturation, suppression of apoptotic signals, and invasion, and eventually leads to cancer cell metastasis. These molecular signaling pathways or networks can have a strong impact on primary tumorigenesis and metastasis. Many immunomodulatory plant natural products have quite specific effects on these various signaling pathways, and are thus being actively evaluated for use as anticancer and anti-inflammatory disease remedies $[1,9,13,29,30]$.

Proanthocyanidins in grapes reduce the UVB radiation-induced increase in levels of IL-10 in skin and enhance the expression of IL-12 in test skin [113]. EGCG inhibits both tumor cell growth and the activation of epidermal growth factor receptor (EGFR) and human EGFR-2 signaling pathways in human colon cancer cells [114]. EGCG also inhibits hypoxia- and serum-induced HIF$1 \alpha$ protein accumulation and VEGF expression in human cervical carcinoma and hepatoma HepG2 cells [115], and inhibits the activation of HER-2/neu and downstream signaling pathways in human head, neck, and breast carcinoma cells [116]. Green tea catechins inhibit VEGF-induced angiogenesis in vitro through 


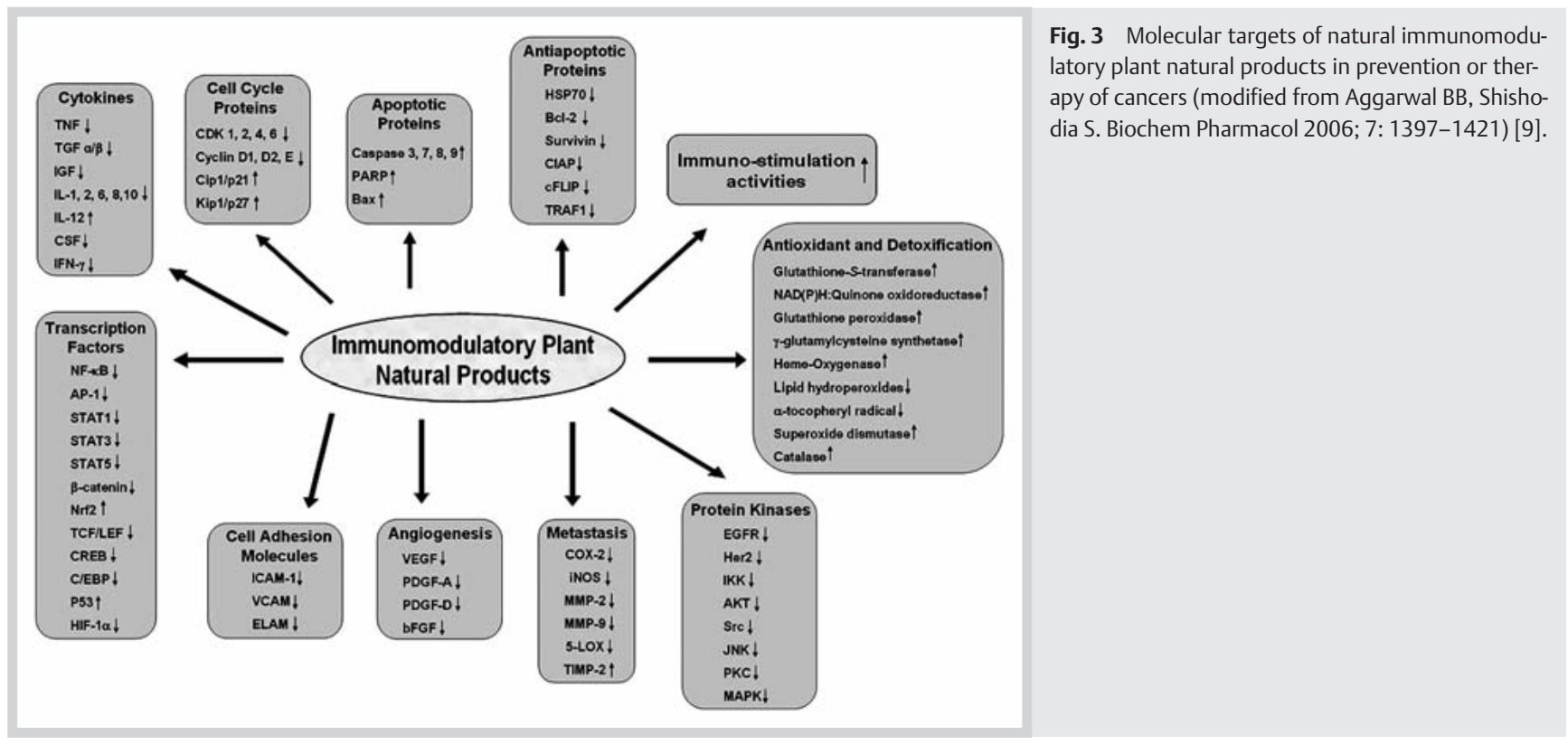

the suppression of VE-cadherin phosphorylation and inactivation of the AKT molecule [117]. Recently, we observed that shikonin from purple groomwell (Lithospermum erythrorhizon) suppresses LPS-induced TNF- $\alpha$ expression in human acute monocytic leukemia THP-1 cells, by the interesting route of blocking the premRNA splicing activity mediated by the 3'-UTR element. Shikonin can also effectively inhibit transcriptional activity of TNF- $\alpha$, GM-CSF and other inflammatory cytokine genes via interference with their promoter activities [30]. Curcumin inhibits the activation and expression of HER-2, HER-3, and EGFR in breast and colon cancer cells, and thus enhances apoptosis [118,119]. Lycopene from tomatoes markedly inhibits the migration of colorectal cancer cells, reduces the level of circulating insulin-like growth factor (IGF)-I [120] and traps platelet-derived growth factor (PDGF) [121]. The bioactive soybean component, genistein, effectively suppresses the activation of EGFR in human breast cancer cells and inhibited tumor cell proliferation [122].

\section{Angiogenesis and metastasis}

Angiogenesis is the process of forming a new blood supply from preexisting vessels in or near wound or tumor tissue, and is essential for the provision of sufficient essential nutrients and oxygen for tumor growth. Almost forty years ago, Dr. Judah Folkman of Harvard Medical School proposed the working hypotheses and principles that underlie contemporary research in tumor angiogenesis. His work showed that new vessels that formed at the tumor site were not inconsequential bystanders, but were absolutely required for the expansion of the tumor spheroid beyond a diameter of $1.2 \mathrm{~mm}$, at which point the diffusion of nutrients in and waste products out becomes rate-limiting for tumor development [123]. Tumor angiogenesis and metastasis are meticulously regulated by the production of angiogenic stimulators, including members of the FGF, PDGF-A and -D and VEGF families ( Fig. 3). Tumor angiogenesis and cancer metastases are also intrinsically connected. Angiogenesis can facilitate tumor metastasis by providing an efficient route of exit for tumor cells to leave the primary site by entry into the bloodstream [124]. Metastasis is carefully regulated by the combined action of angiogenic factors, cyclooxygenases (like COX-2), and the MMPs that degrade the basement membrane anchoring epithelial cells and pave the way for migration of cancer cells. Matrix metalloproteinases, including collagenases (MMP-1, -8, -13), gelatinases (MMP-2, -9), stromelysins (MMP-3, -7, -10) and elastases (MMP-12), are known to contribute to the various steps of metastasis [125,126]. Although angiogenesis and metastasis belong to the later stages of tumor growth and development, there is good evidence that several anti-inflammatory or immunomodulatory plant natural products may help to switch off angiogenesis and metastasis. For example, resveratrol inhibits VEGF-induced angiogenic effects in human umbilical vein endothelial cells and prevents activation of VE-cadherin and $\beta$-catenin [127]. Proanthocyanidins inhibit fibroblast-conditioned medium-induced expression of MMP-2 and MMP-9 in androgen-insensitive cells (DU145) as well as androgen-sensitive (LnCaP) human prostate carcinoma cells, and reduce the secretion of MMP-2 and MMP-9 by inhibition of MAPK phosphorylation and NF-KB activation [128]. Another procyanidin extracted from Japanese quince fruit effectively inhibits MMP-2 and MMP-9 in human leukemia HL-60 cells [129]. EGCG inhibits tumor growth by reducing the VEGF level and angiogenesis in rat colon cancer [130]; it also suppresses the activities of MMP-2 and MMP-9 in the human fibrosarcoma HT1080 cell line [131]. The phytochemical 6-gingerol inhibits cell adhesion and invasion and decreases the activity of MMP-2 and MMP-9 in the human breast cancer line MDA-MB-231, and also inhibits VEGFinduced cell proliferation and angiogenesis [132]. Curcumin reduces the expression of MMP-2 and MMP-9 and reduces the degradation of extracellular matrix that forms the basis of the angiogenic switch, as well as targeting the non-receptor tyrosine kinases such as Src and FAK, thus inhibiting the downstream PI3K signaling network responsible for the induction of angiogenic and metastatic target genes as COX-2, VEGF and MMPs [133, 134]. The PEITC from edible cruciferous vegetables inhibits the angiogenic features of human umbilical vein endothelial cells in vitro, apparently by suppression of VEGF secretion, the downregulation of VEGF receptor 2 levels, and the inactivation of prosurvival serine-threonine kinase AKT. PEITC treatment also reduces the migration of PC-3 human prostate cancer cells, which correlates with an inactivation of AKT and the suppression for se- 
cretion of VEGF, epidermal growth factor (EGF), and granulocyte colony-stimulating factor (G-CSF) [135].

- Fig. 3 summarizes the currently known cellular physiological and biochemical activities (e.g., protein kinases, cell cycle proteins, cell adhesion molecules), immunoregulation and pathogen defense activites (e.g., immunostimulation, cytokines, transcription factors), and anti-inflammatory and antitumor activities (e.g., apoptotic proteins, antiapoptotic proteins, antioxidant, detoxification, angiogenesis, metastasis) of the various immunomodulatory plant natural products. We believe that future studies will continue to provide useful information on immunomodulatory and chemopreventive activities for candidate anticancer phytomedicines.

\section{In Vivo Studies on the Use of Anti-Inflammatory Plant Natural Products in Cancer Therapy}

Many experimental animal model studies have supported the promise offered by the use of immunomodulatory or anti-inflammatory plants or their constituents to reduce growth or metastasis of primary tumors in vivo. We recently reported that caffeic acid (a phenolic compound present in many fruits and vegetables) suppressed UVB radiation-induced expression of IL-10 and the activation of mitogen-activated protein kinases in mouse skin [136], and that shikonin, extracted from a traditional Chinese medicinal herb, suppressed transcription of the pro-inflammatory cytokine TNF- $\alpha$ promoter (mRNA and protein) in mouse skin [29]. Recently we found that the germacranolide sesquiterpene lactone, deoxyelephantopin, identified from Elephantopus scaber L. (known as "Didancao" in Chinese medicine) shows significant antitumor growth effect on murine glioblastoma GL-261 cells (Kandan Aravindaram, unpublished data) and mammary adenocarcinoma TS/A cells in mice (Lie-Fen Shyur, unpublished data). Elsewhere, curcumin was shown to significantly inhibit AKT and NF-KB signaling pathways, resulting in an inhibition of cell proliferation and induction of apoptosis in PC-3 prostate tumor xenografts in nude mice [137]. Frequent feeding of a $2 \%$ curcumin preparation produced a marked increase in apoptosis and a significant decrease in angiogenesis in nude mice bearing human prostate tumor LnCap cells [138]. Curcumin also inhibits the initiation and promotion of TPA-induced skin cancers in mice and dimethylbenz[a]anthracene (DMBA)-induced oral carcinogenesis in Syrian golden hamsters [139,140], inhibits the azoxymethane (AOM)-induced colon tumors in male F344 rats, prevents tumor growth in C57BL/6J-Apc Min/+ mice, and inhibits growth of AOM-induced rat colon carcinogenesis by suppressing synthesis of prostaglandin (PG) and thromboxane (Tx) [141]. Genistein from soybeans inhibits prostate cancer cell growth by inducing G2/M cell cycle arrest and cell apoptosis, inhibiting the secretion of prostate-specific antigen (PSA), and increasing the effect of radiation treatment against prostate cancers in vivo in both orthotopic and metastatic models [142,143]. Apigenin, a plant flavonoid, suppresses the expression of VEGF and hypoxiainducible factor-1 (HIF-1) in tumor tissues of nude mice with xenografts of A549 human lung cancer cells [144].

Proanthocyanidins have been shown to act as potent antioxidants and free radical scavengers; they inhibit 4T1 murine mammary cancer cell growth in immunocompetent Balb/c mice, resulting in a significant increase in the survival rate of the tumorbearing mice [145]. They also inhibit the metastasis of mammary carcinoma cells from the primary tumor site to the lungs in mice, and inhibit growth of HT29 human colorectal tumors in athymic nude mice without any apparent toxicity [146]. Supplementing the diet with proanthocyanidins was found to effectively inhibit the incidence of DMBA-induced mammary tumors in SpragueDawley rats [147]. Luteolin, a flavonoid present at high levels in several green vegetables, significantly decreases colon cancer incidence and the number of tumor nodules per rat when administered at the initiation and the post-initiation stages of carcinogenesis [148]. Lycopene a natural antioxidant in tomatoes, oranges, papaya, and other fruits, reduces the incidence of lung adenocarcinoma in mice [149], and prevents leiomyoma of the oviduct in the Japanese quail [150]. Sulforaphane inhibits DMBA-induced skin tumorigenesis in $\mathrm{C} 57 \mathrm{BL} / 6$ mice by the induction of antioxidant/phase II detoxification enzymes following their activation via the Nrf2 signaling pathway [151]. EGCG from green tea inhibits growth of 4T1 mouse mammary carcinoma and suppresses metastasis into the lung. It also reduces tumor blood vessel formation in estrogen receptor-negative breast cancers [152], reduces colorectal aberrant crypt foci $(\mathrm{ACF})$ formation, and prevents oncogenic changes in dysplastic ACF in azoxymethanetreated F344 rats [130]. For almost all of the model studies described above, studies exist that seemingly contradict them in one way or another. However, decades of cancer research have led us to appreciate that each model has its own specific advantages and disadvantages. The basic aim of the use of animal models is to understand the causal relationship between human exposure to immunomodulatory plant natural products and cancer therapy.

\section{Conclusions and Future Directions \\ $\nabla$}

A broad spectrum of immunomodulatory or anti-inflammatory plant natural products has been isolated from fruits, vegetables, spices and traditional herbal medicines. They have gained much attention over the last decade for consideration as cancer chemopreventive or therapeutic agents. Advances in cellular, biochemical and molecular biology techniques and experimental approaches using transcriptome, proteome, metabolome and bioinformatics analyses have provided useful new insights into cancer therapeutics, including the exploration of specific plant secondary metabolites as natural products to treat immune imbalances, cancer and inflammation-associated diseases. These plant secondary metabolites may exhibit considerable benefits over synthetic drug approaches as they offer an inexpensive, convenient, readily applicable and accessible health-care approach for prevention, control and management of these diseases. While the specific use of these phytocompounds as medicines, dietary supplements or "health food" ingredients would need concerted future systematic study, especially in terms of translational research rather than the current mechanistic mode, there is continued excitement about their potential. The continued emergence of new evidence for the specific anti-inflammatory and immunomodulatory effects of these plant natural products on cancer cell signaling and molecular target pathways has certainly provided much impetus for future research into their modes of action and their application in cancer prevention and treatment.

A key challenge to researchers is how to best make use of these anti-inflammatory plant natural products for prevention of specific cancers in different populations. The provision of personalized medicines (as advocated in traditional Chinese medicine practice), an awareness of the varying nutritional needs for dif- 
ferent races or individuals, and the availability of modern Western medicine in less developed areas are all considerations for cancer treatment. Moreover, further development of these potent natural products is needed to improve the efficacy of targeted therapeutic strategies to win the battle against cancer in the long run. In addition to the regrettably few ongoing clinical trials involving single anti-inflammatory plant natural products with multiple activities $[153,154]$, combinational approaches using fractionated or crude plant extracts and multiple plant formulations certainly warrant further consideration. In the future, long-term systematic and epidemiological studies of human clinical or nutritional trials of foods with defined anti-inflammatory properties will be essential to gather good evidence of their anticancer potential. With the expected advances in our understanding of the specific signaling pathways, transcription factors and molecular target genes affected by anti-inflammatory or immunomodulatory plant compounds, these natural products offer great promise as anticancer therapeutics or chemopreventive health care agents for a better quality of life for all.

\section{References}

1 Surh YJ. Cancer chemoprevention with dietary phytochemicals. Nat Rev Cancer 2003; 3: 768-780

2 Michels KB, Giovannucci E, Chan AT, Singhania R, Fuchs CS, Willett WC. Fruit and vegetable consumption and colorectal adenomas in the nurses' health study. Cancer Res 2006; 66: 3942-3953

3 Amin ARMR, Kucuk O, Khuri FR, Shin DM. Perspectives for cancer prevention with natural compounds. J Clin Oncol 2009; 27: 2712-2725

4 Tosetti F, Nooman DM, Albini A. Metabolic regulation and redox activity as mechanisms for angioprevention by dietary phytochemicals. Int J Cancer 2009; 125: 1997-2003

5 Fearon ER, Vogelstein B. A genetic model for colorectal carcinogenesis. Cell 1990; 61: 759-767

6 Hanahan D, Weinberg RA. The hallmarks of cancer. Cell 2000; 100: 5770

7 Pan MH, Chai G, Ho CT. Food bioactives, apoptosis, and cancer. Mol Nutr Food Res 2008; 52: 43-52

8 Weinberg RA. The biology of cancer. New York: Taylor and Francis Group, LLC; 2007: 441-451

9 Aggarwal BB, Shishodia S. Molecular targets of dietary agents for prevention and therapy of cancer. Biochem Pharmacol 2006; 7: 13971421

10 Marx J. Inflammation and cancer: the links grows stronger. Science 2004; 306: 966-968

11 Marx J. Cancer's bulwark against immune attack: MDS cells. Science 2008; 319: 154-156

12 Serafini P, Bronte V. Myeloid-derived suppressor cells in cancer. In: Gabrilovich DI, Hurwitz AA, editors. Tumor-induced immune suppression. Heidelberg: Springer; 2008: 157-195

13 Stix G. A malignant flame. Scientific American 2007; 297: 60-67

14 Duvoix A, Blasius R, Delhalle S, Schnekenburger M, Morceau F, Henry E, Dicato $E$, Diederich $M$. Chemopreventive and therapeutic effects of curcumin. Cancer Lett 2005; 223: 181-190

15 Nandakumar $V$, Singh T, Katiyar SK. Multi-targeted prevention and therapy of cancer by proanthocyanidins. Cancer Lett 2008; 269: 378387

16 Reddy L, Odhav B, Bhoola KD. Natural products for cancer prevention: a global perspective. Pharmacol Ther 2003; 99: 1-13

17 Benetou V, Orfanos P, Lagiou P, Trichopoulos D, Boffetta P, Trichopoulos A. Vegetables and fruits in relation to cancer risk: evidence from the Greek EPIC cohort study. Cancer Epidemiol Biomarkers Prev 2008; 17: 387-392

18 Freedman ND, Park Y, Subar AF, Hollenbeck AR, Leitzmann MF, Schatzkin $A$, Abnet CC. Fruit and vegetable intake and head and neck cancer risk in a large United States prospective cohort study. Int J Cancer 2008; 122: 2330-2336

19 Schmidt BM, Erdman JW, Lila MA. Differential effects of blueberry proanthocyanidins on androgen sensitive and insensitive human prostate cancer cell lines. Cancer Lett 2006; 231: 240-246
20 Shammas MA, Neri P, Koley H, Batchu RB, Bertheau RC, Munshi V, Prabhala R, Fulciniti M, Tai YT, Treon SP, Goyal RK, Anderson KC, Munshi NC. Specific killing of multiple myeloma cells by (-)-epigallocatechin-3gallate extracted from green tea: biologic activity and therapeutic implications. Blood 2006; 108: 2804-2810

21 Singh RP, Tyagi A, Sharma G, Mohan S, Agarwal R. Oral silibinin inhibits in vivo human bladder tumor xenograft growth involving downregulaton of survivin. Clin Cancer Res 2008; 14: 300-308

22 Kwon KH, Barve A, Yu S, Huang MT, Kong ANT. Cancer chemoprevention by phytochemicals: potential molecular targets, biomarkers and animal models. Acta Pharmacol Sin 2007; 28: 1409-1421

23 Hayes JD, McMohan M. Molecular basis for the contribution of the antioxidant responsive element to cancer chemoprevention. Cancer Lett 2001; 174: 103-113

24 Manson MM. Cancer prevention - the potential for diet to modulate molecular signalling. Trends Mol Med 2003; 9: 11-18

25 Waltener-Law ME, Wang XL, Law BK, Hall RK, Nawano M, Granner DK. Epigallocatechin gallate, a constituent of green tea, represses hepatic glucose production. J Biol Chem 2002; 277: 34933-34940

26 Bacon JR, Williamson G, Garner RC, Lappin G, Langouët S, Bao Y. Sulforaphane and quercetin modulate PhIP-DNA adduct formation in human HepG2 cells and hepatocytes. Carcinogenesis 2003; 24: 1903-1911

27 Holme AL, Pervaiz S. Resveratrol in cell fate decisions. J Bioenerg Biomembr 2007; 39: 59-63

28 Shen G, Xu C, Hu R, Jain MR, Gopalkrishnan A, Nair S, Huang MT, Chan JY, Kong AN. Modulation of nuclear factor E2-related factor 2-mediated gene expression in mice liver and small intestine by cancer chemopreventive agent curcumin. Mol Cancer Ther 2006; 5: 39-51

29 Staniforth V, Wang SY, Shyur LF, Yang NS. Shikonins, phytocompounds from Lithospermum erythrorhizon, inhibit the transcriptional activation of human tumor necrosis factor $\alpha$ promoter in vivo. J Biol Chem 2004; 279: 5877-5885

30 Chiu SC, Yang NS. Inhibition of tumor necrosis factor-alpha through selective blockade of pre-mRNA splicing by shikonin. Mol Pharmacol 2007: 71: 1640-1645

31 Kong AN, Yu R, Hebbar V, Chen C, Owuor E, Hu R, Ee R, Mandlekar S. Signal transduction events elicited by cancer prevention compounds. Mutat Res 2001; 480-481: 231-241

32 Sarkar FH, Li Y. Targeting multiple signal pathways by chemopreventive agents for cancer prevention and therapy. Acta Pharmacol Sin 2007; 28: 1305-1315

33 Belleri M, Ribatti D, Savio M, Stivala LA, Forti L, Tanghetti E, Alessi P, Coltrini D, Bugatti A, Mitola S, Nicoli S, Vannini V, Presta M. AlphaVbeta3 integrin-dependent antiangiogenic activity of resveratrol stereoisomers. Mol Cancer Ther 2008; 7: 3761-3770

34 Khan N, Afaq F, Mukhtar H. Apoptosis by dietary factors: the suicide solution for delaying cancer growth. Carcinogenesis 2007; 28: 233-239

35 Cram EJ, Liu BD, Bjeldanes LF, Firestone GL. Indole-3-carbinol inhibits CDK6 expression in human MCF-7 breast cancer cells by disrupting sp1 transcription factor interactions with a composite element in the CDK6 gene promoter. J Biol Chem 2001; 276: 22 332-22340

36 Meeran SM, Katiyar SK. Cell cycle control as a basis for cancer chemoprevention through dietary agents. Front Biosci 2008; 13: 2191-2202

37 Liang YC, Tsai SH, Chen L, Lin-Shiau SY, Lin JK. Resveratrol-induced G2 arrest through the inhibition of CDK7 and p 34CDC2 kinases in colon carcinoma HT29 cells. Biochem Pharmacol 2003; 65: 1053-1060

38 Rabi T, Wang L, Banerjee S. Novel triterpenoid 25-hydroxy-3-oxoolean12-en-28-oic acid induces growth arrest and apoptosis in breast cancer cells. Breast Cancer Res Treat 2007; 101: 27-36

39 Wiseman DA, Werner SR, Crowell PL. Cell cycle arrest by the isoprenoids perillyl alcohol, geraniol, and farnesol is mediated by p21 cip1 and p $27^{\text {Kip } 1}$ in human pancreatic adenocarcinoma cells. J Pharmacol Exp Ther 2007; 320: 1163-1170

40 Park MJ, Kim EH, Park IC, Lee HC, Woo SH, Lee JY, Hong YJ, Rhee CH, Cho SH, Shim BS, Lee SH, Hong SI. Curcumin inhibits cell cycle progression of immortalized human umbilical vein endothelial (ECV304) cells by upregulating cyclin-dependent kinase inhibitor, p21WAF1/CIP1, p27KIP1 and p53. Int J Oncol 2002; 21: 379-383

41 Gupta S, Ahmad N, Nieminen AL, Mukhtar H. Growth inhibition, cellcycle dysregulation, and induction of apoptosis by green tea constituent (-)-epigallocatechin-3-gallate in androgen-sensitive and androgen-insensitive human prostate carcinoma cells. Toxicol Appl Pharmacol 2000; 164: 82-90

42 Shen G, Khor TO, Hu R, Yu S, Nair S, Ho CT, Reddy BS, Huang MT, Newmark HL, Kong ANT. Chemoprevention of familial adenomatous polyp- 
osis by natural dietary compounds sulforaphane and dibenzoylmethane alone and in combination in $\mathrm{Apc}^{\mathrm{Min} /+}$ mouse. Cancer Res 2007; 67: 9937-9944

43 Qin J, Xie LP, Zheng XY, Wang YB, Bai Y, Shen HF, Li LC, Dahiya R. A component of green tea, (-)-epigallocatechin-3-gallate, promotes apoptosis in T24 human bladder cancer cells via modulation of the PI3K/AKT pathway and Bcl-2 family proteins. Biochem Biophys Res Commun 2007; 354: 852-857

$44 \mathrm{Xu}$ C, Shen G, Chen C, Gelinas C, Kong AN. Suppression of NF-KB and NFKB-regulated gene expression by sulforaphane and PEITC through IK$\mathrm{B} \alpha$, IKK pathway in human prostate cancer PC-3 cells. Oncogene 2005; 24: 4486-4495

45 Shishodia S, Sethi G, Aggarwal BB. Curcumin: getting back to the roots. Ann NY Acad Sci 2005; 1056: 206-217

46 Singh S, Aggarwal BB. Activation of transcription factor NF-kappa B is suppressed by curcumin (diferuloylmethane). J Biol Chem 1995; 270 : 24995-25000

47 Han SS, Keum YS, Seo HJ, Surh YJ. Curcumin suppresses activation of NFkappaB and AP-1 induced by phorbol ester in cultured human promyelocytic leukemia cells. J Biochem Mol Biol 2002; 35: 337-342

48 Mukhopadhyay A, Bueso-Ramos C, Chatterjee D, Pantazis P, Aggarwal $B B$. Curcumin downregulates cell survival mechanisms in human prostate cancer cell lines. Oncogene 2001; 20: 7597-7609

49 Singh AV, Franke AA, Blackburn GL, Zhou JR. Soy phytochemicals prevent orthotopic growth and metastasis of bladder cancer in mice by alterations of cancer cell proliferation and apoptosis and tumor angiogenesis. Cancer Res 2006; 66: 1851-1858

50 Bode AM, Ma WY, Surh YJ, Dong Z. Inhibition of epidermal growth factor-induced cell transformation and activator protein- 1 activation by [6]-gingerol. Cancer Res 2001; 61: 850-853

51 Han SS, Keum YS, Chun KS, Surh YJ. Suppression of phorbol ester-induced NF-KB activation by capsaicin in cultured human promyelocytic leukemia cells. Arch Pharm Res 2002; 25: 475-479

52 Rahman KM, Li Y, Sarkar FH. Inactivation of AKT and NF-kappaB play important roles during indole-3-carbinol-induced apoptosis in breast cancer cells. Nutr Cancer 2004; 48: 84-94

53 Manna SK, Mukhopadhyay A, Aggarwal BB. Resveratrol suppresses TNF-induced activation of nuclear transcription factors NF-KB, activator protein AP-1 and apoptosis: potential role of reactive oxygen intermediates and lipid peroxidation. J Immunol 2000; 164: 6509-6519

54 Holdenrieder S, Stieber P. Apoptotic markers in cancer. Clin Biochem 2004; 37: 605-617

55 Danial NN, Korsmeyer SJ. Cell death: critical control points. Cell 2004; 116: 205-219

56 Jiang H, Zhang L, Kuo J, Kuo K, Gautam SC, Groc L, Rodriguez AL, Koubi D, Hunter TJ, Corcoran GB, Seidman MD, Levine RA. Resveratrol-induced apoptotic death in human U251 glioma cells. Mol Cancer Ther 2005; 4: $554-561$

57 Alkhalaf M. Resveratrol-induced apoptosis is associated with activation of $\mathrm{p} 53$ and inhibition of protein translation in T47D human breast cancer cells. Pharmacology 2007; 80: 134-143

58 Zhang R, Loganathan S, Humphreys I, Srivastava SK. Benzyl isothiocyanate-induced DNA damage causes $\mathrm{G}_{2} / \mathrm{M}$ cell cycle arrest and apoptosis in human pancreatic cancer cells. J Nutr 2006; 136: 2728-2734

59 Huang D, Shen YC, Wu C, Huang YT, Kung FL, Teng CM, Guh JH. Investigation of extrinsic and intrinsic apoptosis pathways of new clerodane diterpenoids in human prostate cancer in PC-3 cells. Eur J Pharmacol 2004; 503: 17-24

60 Qanungo S, Das M, Haldar S, Basu A. Epigallocatechin-3-gallate induces mitochondrial membrane depolarization and caspase-dependent apoptosis in pancreatic cancer cells. Carcinogenesis 2005; 26: 958-967

61 Siddiqui IA, Zaman N, Aziz MH, Reagan-Shaw SR, Sarfaraz S, Adhami VM, Ahmad N, Raisuddin S, Mukhtar H. Inhibition of CWR22Rnul tumor growth and PSA secretion in athymic nude mice by green and black teas. Carcinogenesis 2006; 27: 833-839

62 Nihal M, Ahmad N, Mukhtar H, Wood GS. Anti-proliferative and proapoptotic effects of (-)-epigallocatechin-3-gallate on human melanoma: possible implications for the chemoprevention of melanoma. Int J Cancer 2005; 114: 513-521

63 Nishikawa T, Nakajima T, Moriguchi M, Jo M, Sekoguchi S, Ishii M, Takashima H, Katagishi T, Kimura H, Minami M, Itoh Y, Kagawa K, Okanoue T. A green tea polyphenol, (-)-epigallocatechin-3-gallate, induces apoptosis of human heptocellular carcinoma, possibly through inhibition of Bcl-2 family proteins. J Hepatol 2006; 44: 1074-1082
64 Horinaka M, Yoshida T, Shiraishi T, Nakata S, Wakada M, Nakanishi R, Nishino H, Matsui H, Sakai T. Luteolin induces apoptosis via death receptor 5 upregulation in human malignant tumor cells. Oncogene 2005; 24: 7180-7189

65 Vargo MA, Voss OH, Poustka F, Cardounel AJ, Grotewold E, Doseff AL. Apigenin-induced apoptosis is mediated by the activation of PKC delta and caspases in leukemia cells. Biochem Pharmacol 2006; 72: 681-692

66 Bush JA, Cheung Jr KJ, Li G. Curcumin induces apoptosis in human melanoma cells through a Fas receptor/caspase-8 pathway independent of p53. Exp Cell Res 2001; 271: 304-314

67 Somasundaram S, Edmund NA, Moore DT, Small GW, Shi YY, Orlowski RZ. Dietary curcumin inhibits chemotherapy-induced apoptosis in models of human breast cancer. Cancer Res 2002; 62: 3868-3875

68 Gao X, Deeb D, Jiang H, Liu YB, Dulchavsky SA, Gautam SC. Curcumin differentially sensitizes malignant glioma cells to TRAIL/Apo2L-mediated apoptosis through activation of procaspases and release of cytochrome $c$ from mitochondria. J Exp Ther Oncol 2005; 5: 39-48

69 Kim YA, Xiao D, Xiao H, Powolny AA, Lew KL, Reilly ML, Zeng Y, Wang Z, Singh SV. Mitochondria-mediated apoptosis by diallyl trisulfide in human prostate cancer cells is associated with generation of reactive oxygen species and regulated by Bax/Bak. Mol Cancer Ther 2007; 6: 15991609

70 Park SY, Cho SJ, Kwon HC, Lee KR, Rhee DK, Pyo S. Caspase-independent cell death by allicin in human epithelial carcinoma cells: involvement of PKA. Cancer Lett 2005; 224: 123-132

71 Zhou HB, Chen JM, Cai JT, Du Q Wu CN. Anticancer activity of genistein on implanted tumor human SG7901 cells in nude mice. World J Gastroenterol 2008; 14: 627-631

72 Su SJ, Chow NH, Kung ML, Hung TC, Chang KL. Effects of soy isoflavones on apoptosis induction and G2-M arrest in human hepatoma cells involvement of caspase- 3 activation, $\mathrm{Bcl}-2$ and $\mathrm{Bcl}-\mathrm{X}_{\mathrm{L}}$ down-regulation, and CDC2 kinase activity. Nutr Cancer 2003; 45: 113-123

73 Jin CY, Park C, Kim GY, Lee SJ, Kim WJ, Choi YH. Genistein enhances TRAIL-induced apoptosis through inhibition of p 38 MAPK signaling in human hepatocellular carcinoma Hep3B cells. Chem Biol Interact 2009; 180: 143-150

74 Afaq F, Syed DN, Malik A, Hadi N, Sarfaraz S, Kweon MH, Khan N, Zaid $M A$, Mukhtar $H$. Delphinidin, an anthocyanidin in pigmented fruits and vegetables, protects human $\mathrm{HaCaT}$ keratinocytes and mouse skin against UVB-mediated oxidative stress and apoptosis. J Invest Dermatol 2007; 127: 222-232

75 Lawrence T, Willoughby DA, Gilroy DW. Anti-inflammatory lipid mediators and insights into the resolution of inflammation. Annu Rev Immunol 2002; 2: 787-795

76 Kaplanski G, Marin V, Montero-Julian F, Mantovani A, Farnarier C. IL-6: a regulator of the transition from neutrophil to monocyte recruitment during inflammation. Trends Immunol 2003; 24: 25-29

77 Karin M, Ben-Neriah Y. Phosphorylation meets ubiquitination: the control of NF-KB activity. Annu Rev Immunol 2000; 18: 621-663

78 Gonda TA, Tu S, Wang TC. Chronic inflammation, the tumor microenvironment and carcinogenesis. Cell Cycle 2009; 8: 2005-2013

79 Moore RJ, Owens DM, Stamp G, Arnott C, Burke F, East N, Holdsworth H, Turner L, Rollins B, Pasparakis M, Kollias G, Balkwill F. Mice deficient in tumor necrosis factor-alpha are resistant to skin carcinogenesis. Nat Med 1999; 5: 828-831

80 Shishodia S, Amin HM, Lai R, Aggarwal BB. Curcumin (diferuloylmethane) inhibits constitutive NF-kappaB activation, induces G1/S arrest, suppresses proliferation, and induces apoptosis in mantle cell lymphoma. Biochem Pharmacol 2005; 70: 700-713

81 Yang F, de Villiers WJ, McClain CJ, Varilek GW. Green tea polyphenols block endotoxin-induced tumor necrosis factor-production and lethality in a murine model. J Nutr 1998; 128: 2334-2340

82 Martin AR, Villegas I, Sanchez-Hidalgo M, de la Lastra CA. The effects of resveratrol, a phytoalexin derived from red wines, on chronic inflammation induced in an experimentally induced colitis model. $\mathrm{Br}$ J Pharmacol 2006; 147: 873-885

83 Posadas I, Terencio MC, Guillen I, Ferrandiz ML, Coloma J, Paya M, Alcaraz MJ. Co-regulation between cyclo-oxygenase-2 and inducible nitric oxide synthase expression in the time-course of murine inflammation. Naunyn Schmiedebergs Arch Pharmacol 2000; 361: 98-106

84 D'Acquisto F, Maiuri MC, de Cristofaro F, Carnuccio R. Nitric oxide prevents inducible cyclooxygenase expression by inhibiting nuclear factor-kappa B and nuclear factor-interleukin-6 activation. Naunyn Schmiedebergs Arch Pharmacol 2001; 364: 157-165 
85 Subbaramaiah K, Dannenberg AJ. Cyclooxygenase 2: a molecular target for cancer prevention and treatment. Trends Pharmacol Sci 2003; 24: 96-102

86 Surh YJ, Chun KS, Cha HH, Han SS, Keum YS, Park KK, Lee SS. Molecular mechanisms underlying chemopreventive activities of anti-inflammatory phytochemicals: down-regulation of COX-2 and iNOS through suppression of NF-kappa B activation. Mutat Res 2001; 480-481: 243-268

87 Tsuji S, Tsujii M. COX-2 and advanced digestive cancer phenotypes. J Gastroenterol 2004; 39: 1224-1225

88 Hussain T, Gupta S, Adhami VM, Mukhtar H. Green tea constituent epigallocatechin-3-gallate selectively inhibits COX-2 without affecting COX-1 expression in human prostate carcinoma cells. Int J Cancer 2005; 113: 660-669

89 Kundu JK, Na HK, Chun KS, Kim YK, Lee SJ, Lee SS, Lee OS, Sim YC, Surh YJ. Inhibition of phorbol ester-induced COX-2 expression by epigallocatechin gallate in mouse skin and cultured human mammary epithelial cells. J Nutr 2003; 133: 3805S-3810S

90 Plummer SM, Holloway KA, Manson MM, Munks RJ, Kaptein A, Farrow $S$, Howells $L$. Inhibition of cyclo-oxygenase 2 expression in colon cells by the chemopreventive agent curcumin involves inhibition of NFkappaB activation via the NIK/IKK signaling complex. Oncogene 1999; 18: 6013-6020

91 Woo KJ, Kwon TK. Sulforaphane suppresses lipopolysaccharide-induced cyclooxygenase-2 (COX-2) expression through the modulation of multiple targets in COX-2 gene promoter. Int Immunopharmacol 2007; 7: 1776-1783

92 Chen KH, Weng MS, Lin JK. Tangeretin suppresses IL-1b-induced cyclooxygenase (COX-2) expression through inhibition of p 38 MAPK, JNK and AKT activation in human lung carcinoma cells. Biochem Pharmacol 2007; 73: 215-227

93 Hou DE, Yanagita T, Uto T, Masuzaki S, Fujii M. Anthocyanidins inhibit cyclooxygenase-2 expression in LPS-evoked macrophages: structureactivity relationship and molecular mechanisms involved. Biochem Pharmacol 2005; 70: 417-425

94 Chung EY, Kim BH, Lee MK, Yun YP, Lee SH, Min KR, Kim Y. Anti-inflammatory effect of the oligomeric stilbene alpha-viniferin and its mode of the action through inhibition of cyclooxygenase- 2 and inducible nitric oxide synthase. Planta Med 2003; 69: 710-714

95 Hong J, Bose M, Ju J, Ryu JH, Chen X, Sang S, Lee MJ, Yang CS. Modulation of arachidonic acid metabolism by curcumin and related beta-diketone derivatives: effects on cytosolic phospholipase A(2), cyclooxygenases and 5-lipooxygenase. Carcinogenesis 2004; 25: 1671-1679

96 Hong J, Smith TJ, Ho CT, August DA, Yang CS. Effects of purified green and black tea polyphenols on cyclooxygenase- and lipooxygenase-dependent metabolism of arachidonic acid in human colon mucosa and colon tumor tissues. Biochem Pharmacol 2001; 62: 1175-1183

97 Reddy DB, Reddanna P. Chebulagic acid (CA) attenuates LPS-induced inflammation by suppressing NF-jB and MAPK activation in RAW 264.7 macrophages. Biochem Biophys Res Commun 2009; 381: 112117

98 Schewe T, Kühn H, Sies H. Flavonoids of cocoa inhibit recombinant human 5-lipoxygenase. J Nutr 2002; 132: 1825-1829

99 Brouet I, Ohshima H. Curcumin, an anti-tumor promoter and anti-inflammatory agent, inhibits induction of nitric oxide synthase in activated macrophages. Biochem Biophys Res Commun 1995; 206: 533540

100 Dey M, Ribnicky D, Kurmukov AG, Raskin I. In vitro and in vivo anti-inflammatory activity of a seed preparation containing phenethylisothiocyanate. J Pharmacol Exp Ther 2006; 317: 326-333

101 Ippoushi K, Azuma K, Ito H, Horie H, Higashio H. [6]-Gingerol inhibits nitric oxide synthesis in activated J774.1 mouse macrophages and prevents peroxynitrite-induced oxidation and nitration reactions. Life Sci 2003; 73: 3427-3437

102 Chen YH, Dai HJ, Chang HP. Suppression of inducible nitric oxide production by indole and isothiocyanate derivatives from Brassica plants in stimulated macrophages. Planta Med 2003; 69: 696-700

103 Darnell Jr JE, Kerr IM, Stark GR. Jak-STAT pathways and transcriptional activation in response to IFNs and other extracellular signaling proteins. Science 1994; 264: 1415-1421

104 Grandis JR, Drenning SD, Chakraborty A, Zhou MY, Zeng Q Pitt AS, Tweardy DJ. Requirement of STAT3 but not STAT1 activation for epidermal growth factor receptor-mediated cell growth in vitro. J Clin Invest 1998; 102: 1385-1392
105 Carlesso N, Frank DA, Griffin JD. Tyrosyl phosphorylation and DNA binding activity of signal transducers and activators of transcription (STAT) proteins in hematopoietic cell lines transformed by $\mathrm{Bcr} / \mathrm{Abl}$. J Exp Med 1996; 183: 811-820

106 Weber-Nordt RM, Egen C, Wehinger J, Ludwig W, Gouilleux-Gruart V, Mertelsmann R, Finke J. Constitutive activation of STAT proteins in primary lymphoid and myeloid leukemia cells and in Epstein-Barr virus (EBV)-related lymphoma cell lines. Blood 1996; 83: 809-816

107 Siddiqui IA, Shukla Y, Adhami VM, Sarfaraz S, Asim M, Hafeez BB, Mukhtar $H$. Suppression of NFkappaB and its regulated gene products by oral administration of green tea polyphenols in an autochthonous mouse prostate cancer model. Pharm Res 2008; 25: 2135-2142

108 Mackenzie GG, Queisser N, Wolfson ML, Fraga CG, Adamo AM, Oteiza PI. Curcumin induces cell-arrest and apoptosis in association with the inhibition of constitutively active NF-KB and STAT3 pathways in Hodgkin's lymphoma cells. Int J Cancer 2008; 123: 56-65

109 Blasius R, Reuter S, Henry E, Dicato M, Diederich M. Curcumin regulates signal transducer and activator of transcription (STAT) expression in K562 cells. Biochem Pharmacol 2006; 72: 1547-1554

110 Wung BS, Hsu MC, Wu CC, Hsieh CW. Resveratrol suppresses IL-6 induced ICAM-1 gene expression in endothelial cells: effects on the inhibition of STAT3 phosphorylation. Life Sci 2005; 78: 389-397

111 Selvendiran K, Koga H, Ueno T, Yoshida T, Maeyama M, Torimura T, Yano $H$, Kojiro $M$, Sata $M$. Luteolin promotes degradation in signal transducer and activator of transcription 3 in human hepatoma cells: an implication for the antitumor potential of flavonoids. Cancer Res 2006; 66: 4826-4834

112 Hämäläinen $M$, Nieminen $R$, Vuorela P, Heinonen $M$, Moilanen E. Antiinflammatory effects of flavonoids: Genistein, kaempferol, quercetin, and daidzein inhibit STAT1 and NF- $k$ B activations, whereas flavone, isorhamnetin, naringenin, and pelargonidin inhibit only NF- $k$ B activation along with their inhibitory effect on iNOS expression and NO production in activated macrophages. Mediators Inflamm 2007; DOI: $10.1155 / 2007 / 45673$

113 Sharma SD, Katiyar SK. Dietary grape-seed proanthocyanidin inhibition of ultraviolet B-induced immune suppression is associated with induction of IL-12. Carcinogenesis 2006; 1: 95-102

114 Shimizu M, Deguchi A, Lim JT, Moriwaki H, Kopelovich L, Weinstein IB. (-)-Epigallocatechin gallate and polyphenon $\mathrm{E}$ inhibit growth and activation of the epidermal growth factor receptor and human epidermal growth factor receptor-2 signaling pathways in human colon cancer cells. Clin Cancer Res 2005; 11: 2735-2746

115 Zhang $Q$ Tang $X$, Lu $Q$ Zhang Z, Rao J, Le AD. Green tea extract and (-)-epigallocatechin-3-gallate inhibit hypoxia- and serum-induced HIF-1 $\alpha$ protein accumulation and VEGF expression in human cervical carcinoma and hepatoma cells. Mol Cancer Ther 2006; 5: 1227-1238

116 Masuda M, Suzui M, Lim JT, Weinstein IB. Epigallocatechin-3-gallate inhibits activation of HER-2/neu and downstream signaling pathways in human head and neck and breast carcinoma cells. Clin Cancer Res 2003; 9: 3486-3491

117 Tang FY, Nguyen N, Meydani M. Green tea catechins inhibit VEGF-induced angiogenesis in vitro through suppression of VE-cadherin phosphorylation and inactivation of AKT molecule. Int J Cancer 2003; 106: 871-878

118 Hong RL, Spohn WH, Hung MC. Curcumin inhibits tyrosine kinase activity of p185neu and also depletes p 185neu. Clin Cancer Res 1999; 5: $1884-1891$

119 Patel BB, Sengupta R, Qazi S, Vachhani H, Yu Y, Rishi AK, Majumdar APN. Curcumin enhances the effects of 5-fluorouracil and oxaliplatin in mediating growth inhibition of colon cancer cells by modulating EGFR and IGF-1R. Int J Cancer 2008; 122: 267-273

120 Vrieling A, Voskuil DW, Bonfrer JM, Korse CM, van Doorn J, Cats A, Depla AC, Timmer R, Witteman BJ, van Leeuwen FE, van't Veer LJ, Rookus MA, Kampmen E. Lycopene supplementation elevates circulating insulinlike growth factor binding protein-1 and -2 concentrations in persons at greater risk of colorectal cancer. Am J Clin Nutr 2007; 86: 1456-1462

121 Chiang HS, Wu WB, Fang JY, Chen DF, Chen BH, Huang CC, Chen YT, Hung CF. Lycopene inhibits PDGF-BB-induced signaling and migration in human dermal fibroblasts through interaction with PDGF-BB. Life Sci 2007; 81: 1509-1517

122 Mai Z, Blackburn GL, Zhou JR. Soy phytochemicals synergistically enhance the preventive effect of tamoxifen on the growth of estrogendependent human breast carcinoma in mice. Carcinogenesis 2007; 28: $1217-1223$ 
123 Folkman J. Tumor angiogenesis: therapeutic implications. N Engl J Med 1971; 285: 1182-1186

124 Dvorak HF, Brown LF, Detmar M, Dvorak AM. Vascular permeability factor/vascular endothelial growth factor, microvascular hyperpermeability, and angiogenesis. Am J Pathol 1995; 146: 1029-1039

125 Polette M, Nawrocki-Raby B, Gilles C, Clavel C, Birembaut P. Tumor invasion and matrix metalloproteinases. Crit Rev Oncol Hematol 2004; 49: $179-186$

126 Zucker S, Vacirca J. Role of matrix metalloproteinases (MMPs) in colorectal cancer. Cancer Metastasis Rev 2004; 23: 101-117

127 Lin MT, Yen ML, Lin CY, Kuo ML. Inhibition of vascular endothelial growth factor-induced angiogenesis by resveratrol through interruption of Src-dependent vascular endothelial cadherin tyrosine phosphorylation. Mol Pharmacol 2003; 64: 1029-1036

128 Vayalil PK, Mittal A, Katiyar SK. Proanthocyanidins from grape seeds inhibit expression of matrix metalloproteinases in human prostate carcinoma cells which is associated with the inhibition of activation of MAPK and NF-KB. Carcinogenesis 2004; 25: 987-995

129 Strek M, Gorlach S, Podsedek A, Sosnowska D, Koziolkiewicz M, Hrabec $Z$. Procyanidin oligomers from Japanese quince (Chaenomeles japonica) fruit inhibit activity of MMP-2 and MMP-9 metalloproteinases. J Agric Food Chem 2007; 16: 6447-6452

130 Xiao H, Hao X, Simi B, Ju J, Jiang H, Reddy BS, Yang CS. Green tea polyphenols inhibit colorectal aberrant crypt foci (ACF) formation and prevent oncogenic changes in dysplastic ACF in azoxymethanetreated F344 rats. Carcinogenesis 2008; 29: 113-119

131 Garbisa S, Sartor L, Biggin S, Salvato B, Benelli R, Albini A. Tumor gelatinases and invasion inhibited by the green tea flavanol epigallocatechin-3-gallate. Cancer 2001; 91: 822-832

132 Lee HS, Seo EY, Kang NE, Kim WK. [6]-Gingerol inhibits metastasis of MDA-MB-231 human breast cancer cells. J Nutr Biochem 2008; 19: 313-319

133 Chen HW, Yu SL, Chen IJ, Li HN, Lin YC, Yao PL, Chao HY, Chien CT, Chen WJ, Lee YT, Yang PC. Anti-invasive gene expression profile of curcumin in lung adenocarcinoma based on a high throughput microarray analysis. Mol Pharmacol 2004; 65: 99-110

134 Leu TH, Su SL, Chuang YC, Maa MC. Direct inhibitory effect of curcumin on Src and focal adhesion kinase activity. Biochem Pharmacol 2003; 66: 2323-2331

135 Xiao D, Singh SV. Phenethyl isothiocyanate inhibits angiogenesis in vitro and ex vivo. Cancer Res 2007; 67: 2239-2246

136 Staniforth V, Chiu LT, Yang NS. Caffeic acid suppresses UVB radiationinduced expression of interleukin-10 and activation of mitogen-activated protein kinases in mouse. Carcinogenesis 2006; 27: 1803-1811

137 Kim JH, Xu C, Keum YS, Reddy B, Conney A, Kong AN. Inhibition of EGFR signaling in human prostate cancer PC-3 cells by combination treatment with beta-phenylethyl isothiocyanate and curcumin. Carcinogenesis 2006; 27: 475-482

138 Dorai T, Cao YC, Dorai B, Buttyan R, Katz AE. Therapeutic potential of curcumin in human prostate cancer. III. Curcumin inhibits proliferation, induces apoptosis, and inhibits angiogenesis of LnCap prostate cancer cells in vivo. Prostate 2001; 47: 293-303

139 Conney AH. Enzyme induction and dietary chemicals as approaches to cancer chemoprevention: the seventh DeWitt S. Goodman lecture. Cancer Res 2003; 63: 7005-7031

140 Li M, Chen X, Liao J, Yang G, Wang S, Josephson Y, Han C, Chen J, Huang $M T$, Yang CS. Inhibition of 7,12-dimethylbenz[a]anthracene (DMBA)induced oral carcinogenesis in hamsters by tea and curcumin. Carcinogenesis 2002; 23: 1307-1313

141 Rao CV, Simi B, Reddy BS. Inhibition by dietary curcumin of azoxymethane-induced ornithine decarboxylase, tyrosine protein kinase, arachidonic acid metabolism and aberrant crypt foci formation in the rat colon. Carcinogenesis 1993; 14: 2219-2225

142 Lakshman M, Xu L, Ananthanarayanan V, Cooper J, Takimoto CH, Helenowski I, Pelling JC, Bergan RC. Dietary genistein inhibits metastasis of human prostate cancer in mice. Cancer Res 2008; 68: 2024-2032

143 Wang Y, Raffoul JJ, Che M, Doerge DR, Joiner MC, Kucuk O, Sarkar FH, Hillman GG. Prostate cancer treatment is enhanced by genistein in vitro and in vivo in a syngeneic orthotopic tumor model. Radiat Res 2006; $166: 73-80$

144 Liu LZ, Fang J, Zhou Q Hu X, Shi X, Jiang BH. Apigenin inhibits expression of vascular endothelial growth factor and angiogenesis in human lung cancer cells: implication of chemoprevention of lung cancer. Mol Pharmacol 2005; 68: 635-643
145 Mantena SK, Baliga MS, Katiyar SK. Grape seed proanthocyanidins induce apoptosis and inhibit metastasis of highly metastatic breast carcinoma cells. Carcinogenesis 2006; 27: 1682-1691

146 Kaur M, Singh RP, Gu M, Agarwal R, Agarwal C. Grape seed extract inhibits in vitro and in vivo growth of human colorectal carcinoma cells. Clin Cancer Res 2006; 12: 6194-6202

147 Davis $C D$, Hord NG. Nutritional "omics" technologies for elucidating the role(s) of bioactive food components in colon cancer prevention. J Nutr 2005; 11: 2694-2697

148 Manju V, Nalini N. Protective role of luteolin in 1,2-dimethylhydrazine induced experimental colon carcinogenesis. Cell Biochem Funct 2007; 25: 189-194

149 Kim DJ, Takasuka N, Nishino H, Tsuda H. Chemoprevention of lung cancer by lycopene. Biofactors 2000; 13: 95-102

150 Sahin K, Ozercan R, Onderci M, Sahin N, Gursu MF, Khachik F, Sarkar FH, Munkarah A, Ali-Fehmi R, Kmak D, Kucuk O. Lycopene supplementation prevents the development of spontaneous smooth muscle tumors of the oviduct in Japanese quail. Nutr Cancer 2004; 50: 181-189

151 Xu C, Huang MT, Shen G, Yuan X, Lin W, Khor TO, Conney AH, Kong ANT. Inhibition of 7,12-dimethylbenz[a]anthracene-induced skin tumorigenesis in C57BL/6 mice by sulforaphane is mediated by nuclear factor E2-related factor 2. Cancer Res 2006; 66: 8293-8296

152 Baliga MS, Meleth S, Katiyar SK. Growth inhibitory and antimetastatic effect of green tea polyphenols on metastasis-specific mouse mammary carcinoma 4T1 cells in vitro and in vivo systems. Clin Cancer Res 2005; 11: 1918-1927

153 Thomasset SC, Berry DP, Garcea G, Marczylo T, Steward WP, Gescher AJ. Dietary polyphenolic phytochemicals - promising cancer chemopreventive agents in humans? A review of their clinical properties. Int J Cancer 2006; 120: 451-458

154 Russo GL. Ins and outs of dietary phytochemicals in cancer chemoprevention. Biochem Pharmacol 2007; 74: 533-544

155 Zhang Y. Cancer-preventive isothiocyanates: measurement of human exposure and mechanism of action. Mutat Res 2004; 555: 173-190

156 Yang YM, Conaway CC, Chiao JW, Wang CX, Amin S, Whysner J, Dai W, Reinhardt J, Chung FL. Inhibition of benzo[a]pyrene-induced lung tumorigenesis in $\mathrm{A} / \mathrm{J}$ mice by dietary $\mathrm{N}$-acetylcysteine conjugates of benzyl and phenethyl isothiocyanates during the post initiation phase is associated with activation of mitogen-activated protein kinases and p53 activity and induction of apoptosis. Cancer Res 2002; 62: $2-7$

157 Verstraeten SV, Hammerstone JF, Keen CL, Fraga CG, Oteiza PI. Antioxidant and membrane effects of procyanidin dimers and trimers isolated from peanut and cocoa. J Agric Food Chem 2005; 53: 5041-5048

158 Ho SC, Hwang LS, Shen YJ, Lin CC. Suppressive effect of a proanthocyanidin-rich extract from longan (Dimocarpus longan Lour.) flowers on nitric oxide production in LPS-stimulated macrophage cells. J Agric Food Chem 2007; 55: 10664-10670

159 El-Alfy AT, Ahmed AA, Fatani AJ. Protective effect of red grape seeds proanthocyanidins against induction of diabetes by alloxan in rats. Pharmacol Res 2005; 52: 264-270

160 Kempuraj D, Madhappan B, Christodoulou S, Boucher W, Cao J, Papadopoulou N, Cetrulo CL, Theoharides TC. Flavonols inhibit proinflammatory mediator release, intracellular calcium ion levels and protein kinase $\mathrm{C}$ theta phosphorylation in human mast cells. Br J Pharmacol 2005; 145: 934-944

161 Dechsupa S, Kothan S, Vergote J, Leger G, Martineau A, Berangeo S, Kosanlavit R, Moretti JL, Mankhetkorn S. Quercetin, siamois 1 and siamois 2 induce apoptosis in human breast cancer MDA-MB-435 cells xenograft in vivo. Cancer Biol Ther 2007; 6: 48-54

162 Ujiki MB, Ding XZ, Salabat MR, Bentrem DJ, Golkar L, Milam B, Talamonti MS, Bell RH, Iwamura T, Adrian TE. Apigenin inhibits pancreatic cancer cell proliferation through G2/M cell cycle arrest. Mol Cancer 2006; 5: 76

163 Shukla S, Gupta S. Apigenin-induced cell cycle arrest is mediated by modulation of MAPK, PI3K-AKT, and loss of Cyclin D1 associated retinoblastoma dephosphorylation in human prostate cancer cells. Cell Cycle 2007; 6: 1102-1115

164 Pan MH, Chen WJ, Lin-Shiau SY, Ho CT, Lin JK. Tangeretin induces cellcycle $\mathrm{G}_{1}$ arrest through inhibiting cyclin-dependent kinases 2 and 4 activities as well as elevating Cdk inhibitors p 21 and p 27 in human colorectal carcinoma cells. Carcinogenesis 2002; 23: 1677-1684

165 Baliga M, Meleth S, Katiyar SK. Growth inhibitory and antimetastatic effect of green tea polyphenols on metastasis-specific mouse mam- 
mary carcinoma $4 \mathrm{~T} 1$ cells in vitro and in vivo systems. Clin Cancer Res 2005; 11: 1918-1927

$166 \mathrm{Na} H K$, Surh YH. Modulation of Nrf2-mediated antioxidant and detoxifying enzyme induction by the green tea polyphenol EGCG. Food Chem Toxicol 2008; 46: 1271-1278

167 Park SS, Kim YN, Jeon YK, Kim YA, Kim JE, Kim H, Kim CW. Genisteininduced apoptosis via AKT signaling pathway in anaplastic large-cell lymphoma. Cancer Chemother Pharmacol 2005; 56: 271-278

168 Shim HY, Park JH, Paik HD, Nah SY, Kim DS, Han YS. Genistein-induced apoptosis of human breast cancer MCF-7 cells involves calpain-caspase and apoptosis signaling kinase 1-p 38 mitogen-activated protein kinase activation cascades. Anticancer Drugs 2007; 18: 649-657

169 Lazzè MC, Savio M, Pizzala R, Cazzalini O, Perucca P, Scovassi AI, Stivala $L A$, Bianchi $L$. Anthocyanins induce cell cycle perturbations and apoptosis in different human cell lines. Carcinogenesis 2004; 25: 14271433

170 Gu M, Singh RP, Dhanalakshmi S, Agarwal C, Agarwal R. Silibinin inhibits inflammatory and angiogenic attributes in photocarcinogenesis in SKH-1 hairless mice. Cancer Res 2007; 67: 3483-3491

171 Palombo P, Fabrizi G, Ruocco V, Ruocco E, Fluhr J, Roberts R, Morganti P. Beneficial long-term effects of combined oral/topical antioxidant treatment with the carotenoids lutein and zeaxanthin on human skin: a double-blind, placebo-controlled study. Skin Pharmacol Physiol 2007; 20: 199-210

172 Chucair AJ, Rotstein NP, Sangiovanni JP, During A, Chew EY, Politi LE. Lutein and zeaxanthin protect photoreceptors from apoptosis induced by oxidative stress: relation with docosahexaenoic acid. Invest Ophthalmol Vis Sci 2007; 48: 5168-5177

173 Hantz H, Young LF, Martin KR. Physiologically attainable concentrations of lycopene induce mitochondrial apoptosis in LNCaP human prostate cancer cells. Exp Biol Med 2005; 230: 171-179

174 Liu C, Russell RM, Wang XD. Lycopene supplementation prevents smoke-induced changes in $\mathrm{p} 53, \mathrm{p} 53$ phosphorylation, cell proliferation, and apoptosis in the gastric mucosa of ferrets. J Nutr 2006; 136: 106-111

175 Srinivasan M, Sudheer AR, Pillai KR, Kumar PR, Sudhakaran PR, Menon $V P$. Lycopene as a natural protector against gamma-radiation induced DNA damage, lipid peroxidation and antioxidant status in primary culture of isolated rat hepatocytes in vitro. Biochim Biophys Acta 2007; 1770: 659-665

176 Yang SC, Huang CC, Chu JS, Chen JR. Effects of $\beta$-carotene on cell viability and antioxidant status of hepatocytes from chronically ethanol-fed rats. Br J Nutr 2004; 92: 209-215
177 Kim Y, Chongviriyaphan N, Liu C, Russell RM, Wang XD. Combined antioxidant ( $\beta$-carotene, $\alpha$-tocopherol and ascorbic acid) supplementation increases the levels of lung retinoic acid and inhibits the activation of mitogen-activated protein kinase in the ferret lung cancer model. Carcinogenesis 2006; 27: 1410-1419

178 Chew BP, Brown CM, Park JS, Mixter PF. Dietary lutein inhibits mouse mammary tumor growth by regulating angiogenesis and apoptosis. Anticancer Res 2003; 23: 3333-3339

179 Lu XG, Zhan LB, Feng BA, Qu MY, Yu LH, Xie JH. Inhibition of growth and metastasis of human gastric cancer implanted in nude mice by d-limonene. World J Gastroenterol 2004; 10: 2140-2144

180 McNally SJ, Harrison EM, Ross JA, Garden OJ, Wigmore SJ. Curcumin induces heme oxygenase 1 through generation of reactive oxygen species, p38 activation and phosphatase inhibition. Int J Mol Med 2007; 19: $165-172$

181 Aziz MH, Shaw SR, Wu J, Longley BJ, Ahmad N. Chemoprevention of skin cancer by grape constituent resveratrol: relevance to human disease? FASEB J 2005; 19: 1193-1195

182 Kode A, Rajendrasozhan S, Caito S, Yang SR, Megson IL, Rahman I. Resveratrol induces glutathione synthesis by activation of Nrf2 and protects against cigarette smoke-mediated oxidative stress in human lung epithelial cells. Am J Physiol 2008; 294: L478-L488

183 Miyoshi N, Nakamura Y, Ueda Y, Abe M, Ozawa Y, Uchida K, Osawa T. Dietary ginger constituents, galanals $A$ and $B$, are potent apoptosis inducers in human T lymphoma Jurkat cells. Cancer Lett 2003; 199: 113-119

184 Takada Y, Andreeff M, Aggarwal BB. Indole-3-carbinol suppresses NFkappaB and Ikappa Balpha kinase activation, causing inhibition of expression of NF-kappaB regulated antiapoptotic and metastatic gene products and enhancement of apoptosis in myeloid and leukemia cells. Blood 2005; 106: 641-649

185 Zhang S, Shen HM, Ong CM. Down-regulation of c-FLIP contributes to the sensitization effect of 3,3'-diindolylmethane on TRAIL-induced apoptosis in cancer cells. Mol Cancer Ther 2005; 4: 1972-1981

186 Herman-Antosiewicz A, Singh SV. Signal transduction pathways leading to cell cycle arrest and apoptosis induction in cancer cells by $\mathrm{Al}$ lium vegetable derived organosulfur compounds: a review. Mutat Res 2004; 555: 121-131

187 Rose DP, Connolly JM. Omega-3 fatty acids as cancer chemopreventive agents. Pharmacol Ther 1999; 83: 217-244 